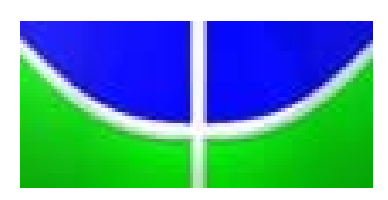

Universidade de Brasília

CET - Centro de Excelência em Turismo

Pós-graduação Lato Sensu

Curso de Especialização em Qualidade de Alimentos

“ANÁLISE DA ESTRUTURA FÍSICA DE UMA UNIDADE DE ALIMENTAÇÃO E NUTRIÇÃO HOSPITALAR DO DISTRITO FEDERAL"

RAIMUNDA CARDOSO PIMENTEL

Brasília - DF

Mar / 2006 
Universidade de Brasília CET - Centro de Excelência em Turismo

Curso de Especialização em Qualidade de Alimentos

\section{"ANÁLISE DA ESTRUTURA FÍSICA DE UMA UNIDADE DE ALIMENTAÇÃO E NUTRIÇÃO HOSPITALAR DO DISTRITO FEDERAL"}

\section{RAIMUNDA CARDOSO PIMENTEL}

Profa. Dra. Wilma Araújo

Professor Coordenador
Profa. Msc Rita de Cássia Akutsu

Professor Orientador
Nome, Titulação

Professor Examinador

"Trabalho apresentado em cumprimento às exigências acadêmicas parciais do curso de pósgraduação lato sensu em Qualidade de Alimentos para a obtenção do grau de Especialista"

Brasília - DF

Mar / 2006 
Pimentel, Raimunda Cardoso

Análise da Estrutura Física de uma Unidade de Alimentação

e Nutrição Hospitalar do Distrito Federal/Raimunda Cardoso

Pimentel.

Monografia - Curso de Especialização em Qualidade de Alimentos Brasília - DF, dezembro de 2005.

Área de Concentração: Nutrição Hospitalar

Orientador: Rita de Cássia Akutsu

1. Unidade de Alimentação e Nutrição 2. Hospital 3. Estrutura Física 
DEDICATÓRIA

Dedico este trabalho àqueles que acreditam e contribuem para a evolução da Ciência da Nutrição, para a preservação da saúde e prolongamento da vida por meio da garantia de alimentos para todos, de forma saudável e segura do ponto de vista higiênico-sanitário. 


\section{AGRADECIMENTOS}

A Deus, luz de nossas vidas, fonte de todos os dons.

Aos professores que doaram com dedicação os seus conhecimentos.

Aos colegas com quem compartilhei conhecimentos.

À coordenação e a todos os funcionários da secretaria.

À jovem nutricionista Naíra Domingos Sé, que ajudou na pesquisa, digitação e revisão da monografia.

Em especial, à grande mestra Profa. Rita de Cássia Akutsu, pelo incentivo à realização deste curso de especialização e por todo o acompanhamento na revisão de literatura. 
"Tudo vale a pena se a alma não é pequena".

Fernando Pessoa 


\section{RESUMO}

O presente trabalho foi realizado com o objetivo de analisar a estrutura física de uma Unidade de Alimentação e Nutrição hospitalar do DF e relacioná-la aos perigos potenciais devido às inadequações. Para tanto, a literatura específica e a legislação brasileira que regulamenta e estabelece os procedimentos higiênicosanitários para as empresas que produzem e manipulam alimentos foram consultados. Por meio de aplicação do check-list de verificação de boas práticas de fabricação da Agência Nacional de Vigilância Sanitária, foram avaliados todos os aspectos relacionados com a edificação e instalações; equipamentos, móveis e utensílios. A UAN analisada apresentou conformidade em $59 \%$ dos itens do check-list, sendo classificado no grupo II da ANVISA. Entretanto, foram encontradas muitas falhas na estrutura física, especialmente no tocante a revestimento de piso, parede, teto, instalações hidráulicas, área de açougue, área de recepção de mercadorias. Esta avaliação da estrutura física foi comparada com avaliação realizada anteriormente a fim de constatar as mudanças. Por fim, foram feitas propostas de melhorias na estrutura física da UAN, com base nas inadequações observadas. Percebeu-se a necessidade de correção das falhas identificadas para garantia da qualidade dos alimentos.

1. Unidade de Alimentação e Nutrição

4. Boas práticas
2. Hospital

5. Check-list
3. Estrutura Física 


\begin{abstract}
The present study endeavours to perform an analysis of the physical structure of a food and nutrition unit in a hospital in Distrito Federal, Brazil, and relate such analysis to potential hazard offered by inadequacies in the structure. For such purpose, the specific literature and the Brazilian legislation that regulates and establishes the sanitary and hygienic procedures for companies that produce and handle food were consulted. Through the essential requisites contained in the sanitary regulation form published by the National Health Surveillance Agency (ANVISA), all the aspects related to the building, facilities, equipment, furnishings and utensils were evaluated. The food and nutrition unit analyzed has fulfilled $59 \%$ of the requisites, being thus placed at group II according to the Agency's guidelines. However, many failures concerning the pavement, walls, ceiling, hydraulic plants, butchery area and pickup area were found. This evaluation of the physical structure was compared to a previously performed one to check which changes were made. At last, suggestions were made for improving the physical structure of the food nutrition unity, based on the observed inadequacies. The necessity to correct the identified failures was pointed out as essential to ensure the good quality of the food.
\end{abstract}

1 - food and nutrition unit in a hospital 2- hospital 3- physical structure 


\section{S U M Á R I O}

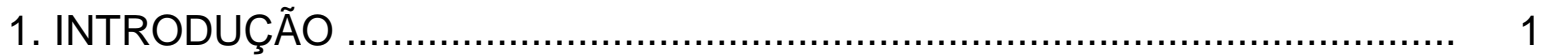

1.1 Identificação e Justificativa ...................................................... 1

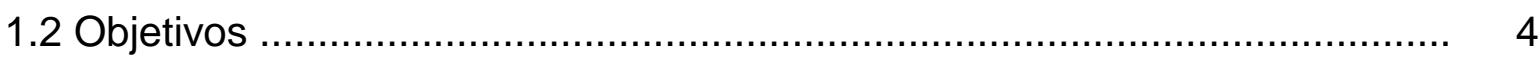

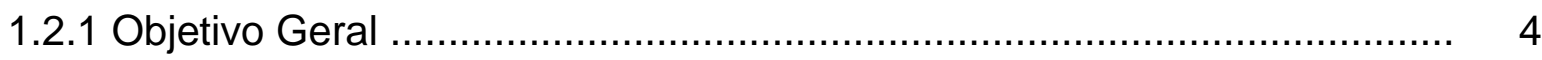

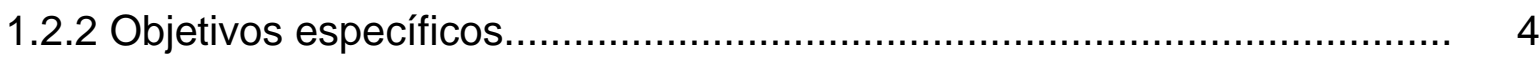

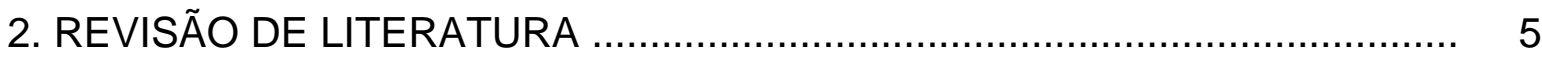

2.1 Considerações Iniciais ................................................................... 5

2.1.1 Nutricionista - profissional responsável técnico da UAN ....................... 5

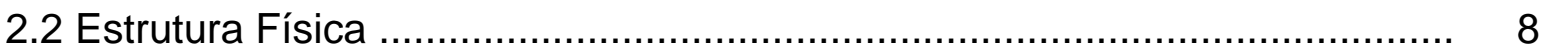

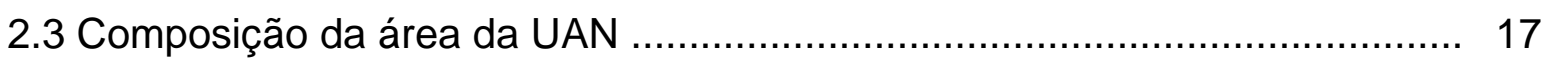

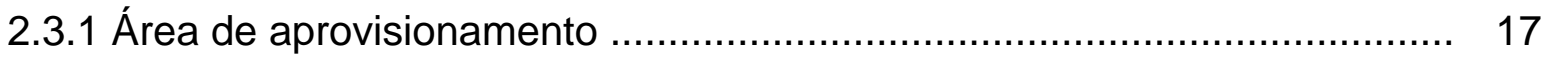

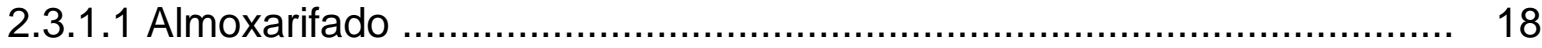

2.3.1.2 Área para armazenamento de alimentos sob temperatura controlada ... 18

2.3.2 Área de processamento .......................................................... 19

2.3.2.1 Área de pré-preparo................................................................ 20

2.3.2.2 Área para cocção.............................................................. 20

2.3 .3 Área de distribuição................................................................ 21

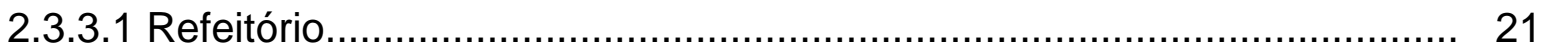

2.3.4 Área para higienização........................................................... 21

2.3.4.1 Área para higienização dos utensílios utilizados no processamento...... 21

2.3.4.2 Área para higienização de bandejas........................................... 22

2.3.4.3 Área para higienização de carros............................................. 22

2.3.4.4 Área para higienização do material de limpeza................................ 22

2.3 .5 Sala de administração........................................................... 23

2.3.6 Área para instalações sanitárias e vestiários................................... 23

2.3.7 Área para guarda de recipientes.............................................. 23

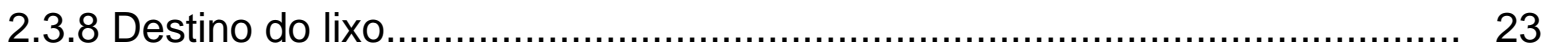

2.3.9 Área para guarda de recipientes de gás.............................................. 24

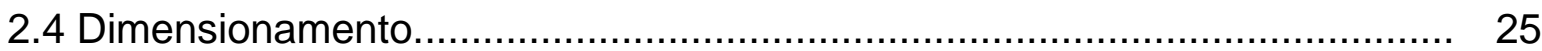

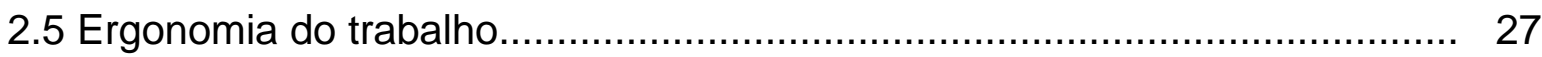

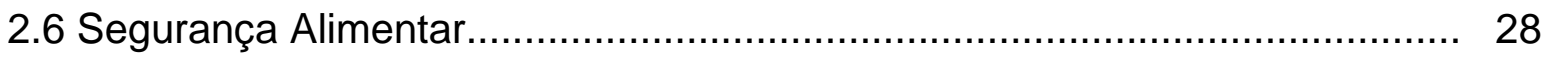

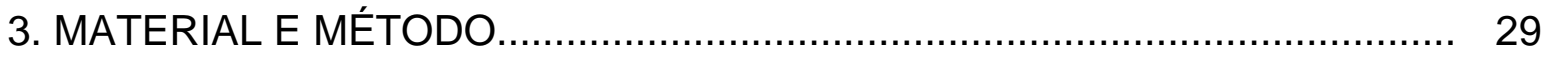




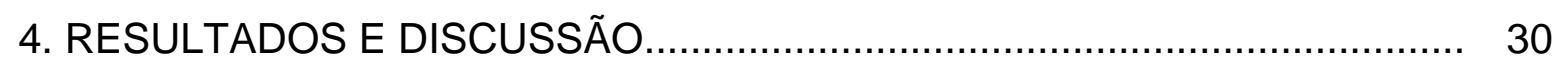

4.1. Identificação do local............................................................................. 30

4.2 A Unidade de Alimentação e Nutrição (UAN) ............................................ 31

4.3 Análise da Estrutura Física da UAN............................................................ 36

4.3.1 Localização............................................................................... 36

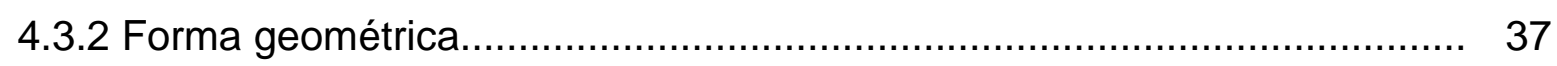

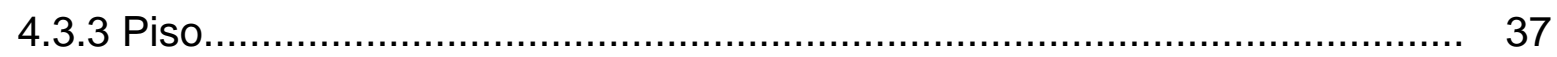

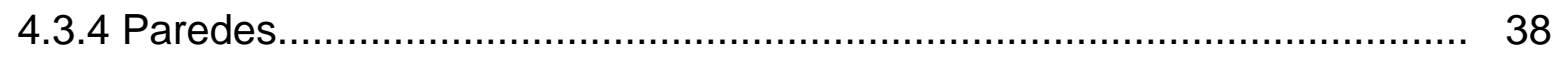

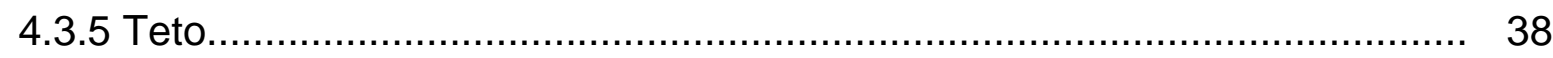

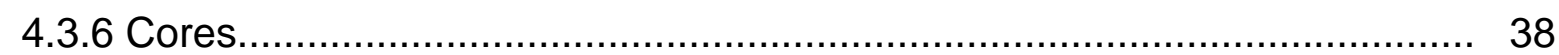

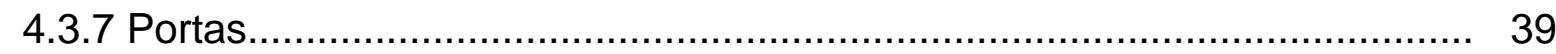

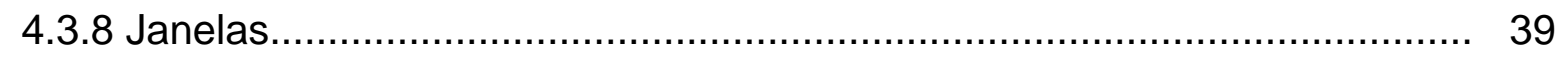

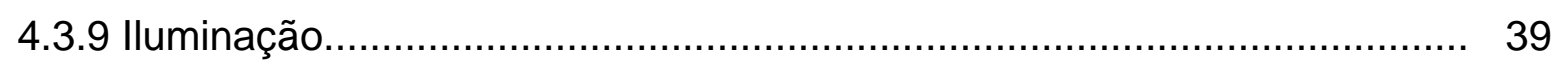

4.3.10 Ventilação, temperatura e umidade................................................... 40

4.3.11 Ruído................................................................................... 41

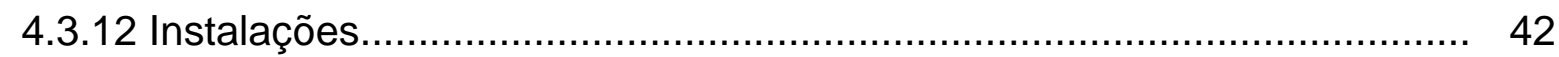

4.3.13 Instalações sanitárias e vestiários..................................................... 43

4.3.14 Manejo de resíduos..................................................................... 43

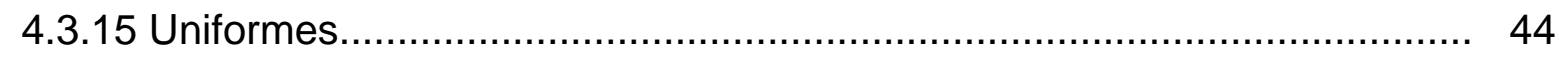

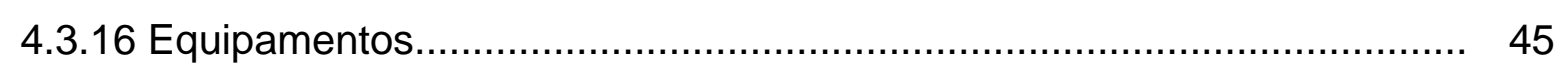

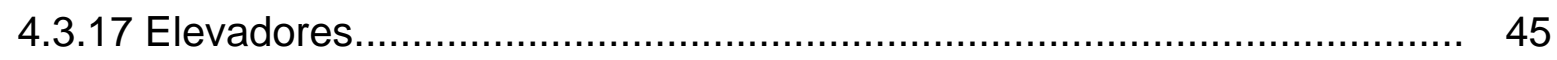

4.3.18 Móveis e Utensílios........................................................................... 45

4.3.19 Dimensionamento da estrutura física................................................ 46

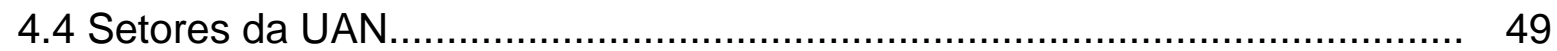

4.4.1 Área de aprovisionamento.................................................................. 49

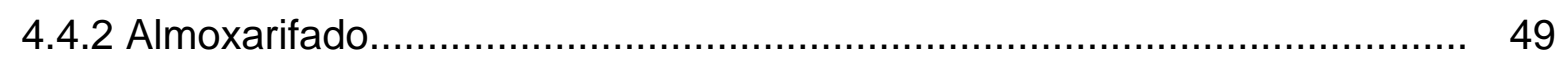

4.4.3 Câmaras Frigoríficas............................................................................ 50

4.4.4 Área de Pré-preparo...................................................................... 50

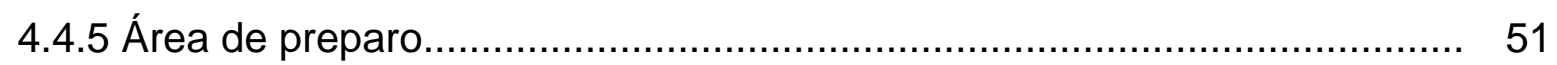

4.4.6 Área de distribuição.............................................................................. 52

4.4.7 Área para higienização ……....................................................... 53

4.5 Classificação do estabelecimento....................................................... 53

4.6 Comparação da estrutura da UAN atual em relação à avaliação anterior..... 53 
4.7 Propostas para melhorar a estrutura física....................................... 55

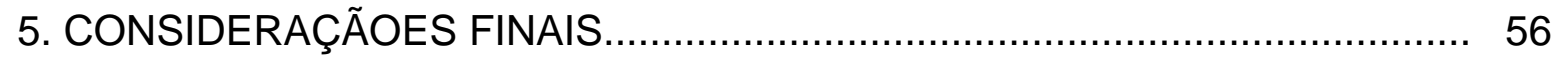

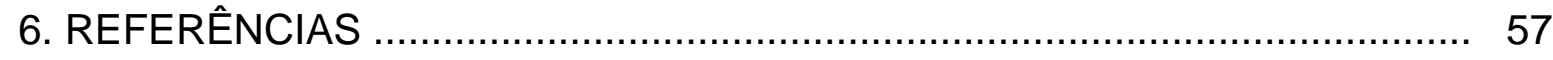

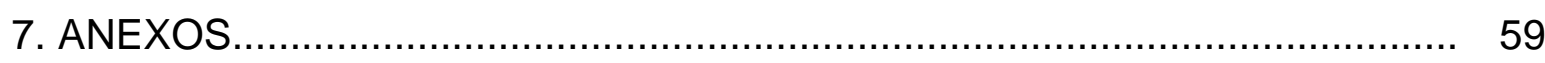

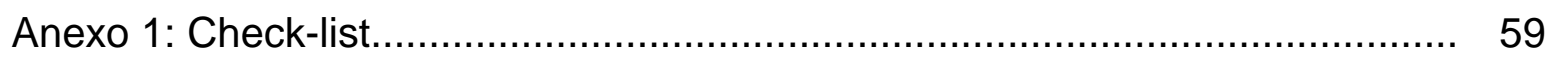

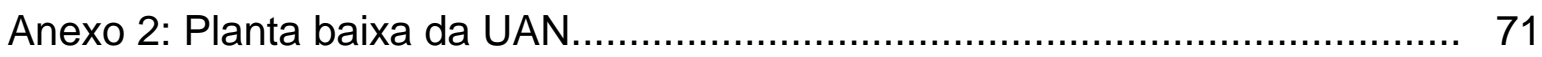




\section{LISTA DE ILUSTRAÇÕES}

Figura 1. Níveis de iluminação recomendados

Figura 2. As cores e seu índice de reflexão

Figura 3. Área total da UAN

Figura 4. Número médio de refeições servidas pela UAN do HUB em novembro de 2005

Figura 5. Refeições servidas no refeitório e clínicas do HUB no ano de 2004

Figura 6. Gasto semestral e anual, em reais, relativos à compra de insumos para a UAN do HUB em 2004

Figura 7. : Distribuição das áreas da UAN

Figura 8. Temperatura e umidade da UAN 


\section{SIGLAS E ABREVIATURAS}

$\begin{array}{ll}\text { APPCC } & \text { Análise de Perigos e Pontos Críticos de Controle } \\ \text { CET } & \text { Centro de Excelência em Turismo } \\ \text { POP } & \text { Procedimentos Operacionais Padronizados } \\ \text { UAN } & \text { Unidade de Alimentação e Nutrição } \\ \text { UnB } & \text { Universidade de Brasília }\end{array}$




\section{INTRODUÇÃO}

\subsection{IDENTIFICAÇÃO E JUSTIFICATIVA}

A Unidade de Alimentação e Nutrição (UAN) é o estabelecimento onde são produzidas as refeições para uma coletividade sadia ou enferma e tem como objetivo principal a promoção da saúde de sua clientela por meio de uma alimentação nutricionalmente adequada e equilibrada (TEIXEIRA et al, 2004).

Segundo Mezomo (2004), a UAN hospitalar tem as seguintes metas:

- Preparar e distribuir cientificamente a alimentação destinada aos pacientes, funcionários, acompanhantes e visitantes do hospital, obedecendo às dietas e cardápios preestabelecidos pela própria unidade;

- Prever e prover todos os gêneros alimentícios e equipamentos necessários ao desenvolvimento de suas atividades;

- Receber, conferir, armazenar, registrar, controlar e distribuir os gêneros alimentícios e demais materiais da unidade;

- Elaborar programas de educação nutricional para pacientes e funcionários;

- Elaborar programas de treinamento dos funcionários;

- Programar estágios externos para o pessoal da UAN, visando atualização profissional;

- Fomentar a pesquisa no campo da nutrição;

- Colaborar com as instituições educacionais na formação de profissionais de nutrição e na área de saúde.

A fim de atingir as metas, o planejamento adequado é essencial. $O$ Planejamento de uma UAN é realizado em diversas etapas sucessivas e envolve uma série de conhecimentos. Durante os estudos de construção de um hospital, deverá estar presente o nutricionista, observando os mínimos detalhes da planta física, dimensionamento, localização e compra de equipamentos, levando em consideração a organização, fluxos e atividades a serem desenvolvidas na Unidade de Nutrição (MEZOMO, 2004). 
Vários fatores merecem atenção quando se pensa em área física de UAN hospitalar: tipo de hospital, capacidade do hospital, número de leitos, número total de comensais, levantamento de todos os equipamentos necessários, política de compras, além de dotação do pessoal necessário para o serviço e jornada de trabalho (MEZOMO, 2004).

Um planejamento físico respaldado no reconhecimento das características específicas do funcionamento das UAN's, além da economia de movimentos e evidente racionalização das ações, poderá evitar fatores negativos de operacionalização, dentre os quais: interrupção no fluxo de operações, cruzamentos desnecessários de gêneros e funcionários, má utilização dos equipamentos, limitação no planejamento dos cardápios por falta de equipamentos apropriados, equipamentos ociosos ou mal localizados, causando congestionamento na circulação, deficiência no sistema de ventilação e, inclusive, aumento de custos (TEIXEIRA et al, 2004).

Alguns aspectos do planejamento físico refletem-se diretamente nas condições higiênicas da UAN, como é o caso da escolha de material adequado para revestimento dos pisos e paredes, dimensionamento e localização corretos dos ralos dos pisos para escoamento da água, com a dupla função de facilitar as operações de limpeza e diminuir os acidentes de trabalho.

Um importante aspecto abordado na estrutura física é a ambiência do trabalho, que é considerada o conjunto de elementos que condicionam as atividades administrativas e operacionais e determinam, em grande parte, a qualidade e quantidade de trabalho produzido.

Vários são os fatores que devem ser considerados na ambiência do trabalho, alguns interferindo diretamente na segurança e saúde do trabalhador e outros proporcionando condições adequadas de trabalho. Dentre os primeiros pode-se citar: pisos, instalações elétricas, mecânicas e de vapor, iluminação, ventilação, ruídos, temperatura e umidade e ergonomia. Dentre os que propiciam condições favoráveis ao trabalho podem ser mencionados: cor, localização, configuração geométrica, revestimento das paredes, esquadrias, etc. 
Percebe-se, portanto, a importância da estrutura física de uma UAN na qualidade dos alimentos e segurança do trabalho, sendo necessário que ela seja avaliada periodicamente para detecção e correção das falhas diagnosticadas.

Objetivando melhorar a compreensão, este trabalho foi dividido em 5 partes. Na primeira parte é apresentada uma breve exposição sobre as metas das Unidades de Alimentação e Nutrição, o papel do nutricionista nessas Unidades, o objetivo geral e específico do presente estudo. A segunda parte traz a revisão de literatura abordando todos os aspectos da estrutura física de UAN's e comentários sobre a relação entre a estrutura física a, segurança alimentar e a ergonomia. Na terceira parte, é apresentada a metodologia utilizada para o desenvolvimento do trabalho. A quarta parte apresenta a instituição estudada, aborda os resultados encontrados com a avaliação da estrutura física da UAN, sendo discutido cada item, feito comparações e recomendações. A última parte encerra o trabalho com as conclusões da autora. 


\subsection{OBJETIVOS}

\subsubsection{Objetivo Geral}

Analisar a estrutura física de uma Unidade de Alimentação e Nutrição Hospitalar.

\subsubsection{Objetivos Específicos}

- Identificar a estrutura física da UAN;

- Avaliar adequação da estrutura física da UAN;

- Comparar a avaliação da estrutura física da UAN com avaliação realizada anteriormente;

- Propor melhorias na estrutura física, com base nas inadequações observadas. 


\section{REVISÃO DE LITERATURA}

Neste capítulo, serão tecidas considerações sobre o papel dos nutricionistas nas Unidades de Alimentação e Nutrição. Em seguida, serão abordados todos os aspectos da estrutura física de UAN's e comentários sobre a relação entre a estrutura física a segurança alimentar e a ergonomia.

\subsection{CONSIDERAÇÕES INICIAIS}

\subsubsection{Nutricionista - Profissional responsável técnico da UAN}

Mary Swartz Rose, em 1935 (apud TODHUNTER, 1965), elaborou uma nova concepção de Dietética que possibilitou a ampliação do campo de trabalho do nutricionista. Tal concepção é até hoje aceita pelos estudiosos da área e amplia a noção de Dietética, passando a concebê-la como aplicação da ciência da nutrição a indivíduos ou grupos de indivíduos sadios ou enfermos. A ampliação desse conceito fez com que suas funções passassem a incluir não só a recuperação, mas a prevenção e manutenção e, mais recentemente, a promoção da saúde que podem ser desenvolvidas em várias instituições.

No Brasil, a prática profissional do nutricionista esteve, desde o seu nascimento, vinculada às políticas de Estado, entre as quais destacam-se, respectivamente, duas que marcaram o processo de criação e consolidação da profissão: a criação, em 1940, do Serviço de Alimentação e Previdência Social SAPS, e a implementação do Programa de Alimentação do Trabalhador - PAT em 1976 (VASCONCELOS, 2002).

Foi em um cenário de industrialização e urbanização, caracterizado pela alta concentração das atividades econômicas, longas jornadas de trabalho e pouco tempo livre para o lazer e o descanso que se consolidou a profissão de nutricionista (AKUTSU, 2001).

O nutricionista é o profissional que atua na promoção e recuperação da saúde e prevenção de doenças, com formação generalista na área de alimentação e 
nutrição, pautado em princípios éticos, com reflexão sobre a realidade econômica, política e cultural.

Compete ao Nutricionista, no exercício de suas atribuições em Unidades de Alimentação e Nutrição, planejar, organizar, dirigir, supervisionar e avaliar os serviços de alimentação e nutrição; realizar assistência e educação nutricional à coletividade ou indivíduos sadios ou enfermos em instituições públicas e privadas (CFN, 2005).

Para realizar as suas atribuições, o nutricionista deverá desenvolver as seguintes atividades obrigatórias (CFN, 2005):

- Planejar e supervisionar a execução da adequação de instalações físicas, equipamentos e utensílios, de acordo com as inovações tecnológicas;

- Planejar e supervisionar o dimensionamento, a seleção, a compra e a manutenção de equipamentos e utensílios;

- Planejar, elaborar e avaliar os cardápios, adequando-os ao perfil epidemiológico da clientela atendida, respeitando os hábitos alimentares;

- Planejar cardápios de acordo com as necessidades de sua clientela;

- Planejar, coordenar e supervisionar as atividades de seleção de fornecedores, procedência dos alimentos, bem como sua compra, recebimento e armazenamento;

- Coordenar e executar os cálculos de valor nutritivo, rendimento e custo das refeições/preparações culinárias;

- Planejar, implantar, coordenar e supervisionar as atividades de pré-preparo, preparo, distribuição e transporte de refeições e/ou preparações culinárias;

- Coordenar o desenvolvimento de receituários e respectivas fichas técnicas, avaliando periodicamente as preparações culinárias;

- Estabelecer e implantar procedimentos operacionais padronizados e métodos de controle de qualidade de alimentos, em conformidade com a legislação vigente; 
- Coordenar e supervisionar métodos de controle das qualidades organolépticas das refeições e/ou preparações, por meio de testes de análise sensorial de alimentos;

- Elaborar e implantar o Manual de Boas Práticas, avaliando e atualizando os procedimentos operacionais padronizados (POP) sempre que necessário;

- Planejar, implantar, coordenar e supervisionar as atividades de higienização de ambientes, veículos de transporte de alimentos, equipamentos e utensílios;

- Planejar, coordenar, supervisionar e/ou executar programas de treinamento, atualização e aperfeiçoamento de colaboradores;

- Promover programas de educação alimentar e nutricional para clientes;

- Participar da elaboração dos critérios técnicos que subsidiam a celebração de contratos na área de prestação de serviços de fornecimento de refeições para coletividade;

- Detectar e encaminhar ao hierárquico superior e às autoridades competentes, relatórios sobre condições da UAN impeditivas da boa prática profissional e/ou que coloquem em risco a saúde humana;

- Elaborar o plano de trabalho anual, contemplando os procedimentos adotados para o desenvolvimento das atribuições;

- Efetuar controle periódico dos trabalhos executados;

- Colaborar com as autoridades de fiscalização profissional e/ou sanitária;

São atividades complementares do nutricionista na UAN (CFN, 2005):

- Participar do planejamento e gestão dos recursos econômico-financeiros da UAN;

- Participar do planejamento, implantação e execução de projetos de estrutura física da UAN; 
- Implantar e supervisionar o controle periódico das sobras, do resto-ingestão e análise de desperdícios, promovendo a consciência social, ecológica e ambiental;

- Participar da definição do perfil, do recrutamento, da seleção e avaliação de desempenho de colaboradores;

- Planejar, supervisionar e/ou executar as atividades referentes a informações nutricionais e técnicas de atendimento direto aos clientes/pacientes;

- Planejar e/ou executar eventos, visando à conscientização dos empresários da área e representantes de instituições, quanto à responsabilidade dos mesmos na saúde coletiva e divulgando o papel do Nutricionista;

- Organizar a visitação de clientes às áreas da UAN;

- Realizar e divulgar estudos e pesquisas relacionados à sua área de atuação, promovendo o intercâmbio técnico-científico;

- Prestar serviços de auditoria, consultoria e assessoria na área;

- Participar do planejamento e execução de programas de treinamento, estágios para alunos de nutrição e educação continuada para profissionais de saúde, desde que sejam preservadas as atribuições privativas do nutricionista.

Sendo o responsável técnico da UAN, além de todas essas atribuições acima descritas, o nutricionista é quem tem o conhecimento técnico e qualificação para planejar, avaliar e adequar a estrutura física para proporcionar uma atenção dietética que contemple tanto a qualidade nutricional quanto sensorial aos clientes.

\subsection{ESTRUTURA FÍSICA}

A estrutura física adequada da UAN objetiva garantir instalações adequadas e funcionais, assegurando a operacionalização dentro das mais rígidas normas técnicas e de higiene, bem como a qualidade da produção do serviço prestado aos comensais, sejam eles pacientes ou funcionários (MEZOMO, 2004). 
Vários são os fatores que devem ser avaliados na estrutura física.

A lluminação exerce uma forte influência no comportamento das pessoas. Sua utilização adequada evita doenças visuais, aumenta a eficiência do trabalho e diminui o número de acidentes. Deve ser distribuída uniformemente pelo ambiente, evitando ofuscamento, sombras, reflexos fortes e contrastes excessivos. Deve incidir numa direção que não prejudique os movimentos nem a visão das pessoas que ali trabalham. A correta distribuição garante ainda melhor limpeza do local e melhor inspeção dos alimentos, tanto na recepção como na produção (MEZOMO, 2004; SILVA FILHO, 1996).

Nessa direção, as janelas ou outros tipos de aberturas deverão estar localizados de forma que a penetração direta do sol sobre a superfície de trabalho não seja permitida. A iluminação mais recomendada para a UAN é a natural que, sendo um acelerador de trocas orgânicas, funciona como bactericida, age estimulando as funções do organismo e é mais econômica (TEIXEIRA et al, 2004).

No entanto, a iluminação natural não dispensa a instalação de rede elétrica. $O$ nível mínimo de iluminação deverá situar-se em torno de $200 \mathrm{lux} / \mathrm{m}^{2}$ (Quadro 1). A Legislação recomenda para as UAN, $150 \mathrm{~W} / 6 \mathrm{~m}^{2}$ para refeitórios e $150 \mathrm{~W} / 4 \mathrm{~m}^{2}$ para a área de processamento, considerando, em ambos os casos, pé direito máximo de 3 metros (TEIXEIRA et al, 2004).

Quadro 1: Níveis de iluminação recomendados

\begin{tabular}{|l|c|}
\hline Setores da UAN & Mínimo de Lux/m ${ }^{2}$ \\
\hline Áreas Gerais & 200 \\
\hline Áreas de pré-preparo & 400 \\
\hline Área de preparo & 400 \\
\hline Higienização & 400 \\
\hline Distribuição & 400 \\
\hline Armazenamento & 200 \\
\hline
\end{tabular}

Fonte: Silva Filho, 1996

Em condições normais, a luz do dia com incidência direta, chega à faixa de 5000 a 6000 lux. Então, pode-se aproveitar de 4\% a 8\% dessa luz dentro da área de trabalho (SILVA FILHO, 1996).

As lâmpadas mais indicadas são do tipo fluorescente, pois distribuem uniformemente a iluminação nos ambientes, proporciona conforto, não produz calor, 
é mais econômica e sua forma tubular produz menos concentração de brilho. As luminárias devem ser resistentes à corrosão e ter proteção especial, tipo blindada, contra vapor de água (SILVA FILHO, 1996).

Um outro ponto a ser destacado em relação à estrutura física é a ventilação, que estando adequada assegura um certo grau de conforto térmico, indispensável à realização de qualquer tipo de trabalho e proporciona a renovação do ar, muito importante em áreas de produção, devido à exalação constante de vapores provenientes do processo de cocção. O conforto térmico na UAN pode ser assegurado pela abertura nas paredes que permitam circulação natural do ar. Quando isso não é possível, o mais indicado é recorrer a meios artificiais, como ventiladores, circuladores, exaustores e condicionadores de ar. Uma temperatura entre $22^{\circ} \mathrm{C}$ e $26^{\circ} \mathrm{C}$, com umidade relativa de $50 \%$ a $60 \%$ é considerada compatível com as operações realizadas numa UAN (ABERC, 1995).

Em complemento à ventilação e como um dos itens do conforto ambiental está a umidade. A elevação da umidade para valores acima dos níveis recomendados contribui para um maior risco de decomposição dos alimentos que se encontram em processo de elaboração. A umidade cedida às paredes pela grande disponibilidade de água no ambiente, como conseqüência da evaporação que acontece no cozimento e pelo uso da água na área de produção, possibilita o aparecimento de fungos nas paredes e teto. Daí a importância de manter a área de produção sempre seca em todas as suas dependências em todo o tempo (TRIGO, 1999).

No momento de aquisição de equipamentos que garantem conforto térmico, deve-se avaliar o nível de ruídos gerados. Devido à quantidade de máquinas, sistema de exaustão, manipulação de utensílios, água, vapor, ressonâncias nas superfícies metálicas, etc, existe dentro da UAN uma quantidade grande de ruídos (SILVA FILHO, 1996).

Noutra direção, mas em complemento ao conceito de conforto ambiental, está o conforto sonoro. Um ambiente de trabalho com sons discordantes e irritantes conduz a ações negativas, interferindo na execução de qualquer tarefa. O ruído é considerado uma das causas de doenças psicológicas, ocasionando elevação da pressão sangüínea, redução das secreções salivares e gástricas, perda da acuidade auditiva, neurose, etc. A capacidade auditiva do homem vai de 0 a 120 decibéis. 
Porém, ruídos entre 70 a 80 decibéis já prejudicam a saúde e, passando dos 80 db, prejudicam o aparelho auditivo (TEIXEIRA et al, 2004).

Deve-se manter o nível de ruído em torno de 45 a $55 \mathrm{db}$, que é bem razoável e não causa fadiga nem irritação por permanência prolongada (SILVA FILHO, 1996).

Para reduzir o barulho nas áreas de produção podem ser tomadas algumas medidas: evitar projetos de UAN com formas circulares ou côncavas, por concentrarem e conduzirem o som; não instalar equipamentos nos cantos ou junto às paredes para evitar a reflexão do som; empregar materiais acústicos e isolantes para o teto e as paredes; adquirir equipamentos e carros silenciosos que se movam sobre rodízios de borracha.

Além de conforto térmico e auditivo, o bom planejamento físico também prevê o conforto visual, que se dá pela escolha adequada das cores. Esta escolha, no ambiente de trabalho, está diretamente relacionada ao seu índice de reflexão - a quantidade de luz que volta ao meio ambiente, após incidir numa superfície (Quadro 2). As cores têm o poder de absorver luz em maior ou menor intensidade, daí sua importância no ambiente de trabalho. As cores utilizadas no teto e no alto das paredes devem ter um percentual de reflexão acima de 80\%. Para as paredes, abaixo da altura dos olhos, o índice de reflexão deve estar entre 50\% e 75\% e, para os pisos, as cores recomendadas devem corresponder a um índice de reflexão de 15\% a 30\% (TEIXEIRA et al, 2004).

Quadro 2: As cores e seu índice de reflexão

\begin{tabular}{|l|l|}
\hline Cores & Índice de reflexão \\
\hline Branco & $80 \%$ a $85 \%$ \\
\hline Creme & $55 \%$ a $70 \%$ \\
\hline Amarelo claro & $45 \%$ a $60 \%$ \\
\hline Verde claro & $35 \%$ a $55 \%$ \\
\hline Verde escuro & $10 \%$ a $35 \%$ \\
\hline Azul claro & $30 \%$ a $50 \%$ \\
\hline Azul & $10 \%$ a $25 \%$ \\
\hline Preto & $5 \%$ a $10 \%$ \\
\hline Rosa claro & $55 \%$ a $60 \%$ \\
\hline
\end{tabular}




\begin{tabular}{|l|l|}
\hline Vermelho claro & $25 \%$ a $40 \%$ \\
\hline Vermelho escuro & $10 \%$ a $25 \%$ \\
\hline Bege & $40 \%$ a $45 \%$ \\
\hline Cinza claro & $40 \%$ a $50 \%$ \\
\hline Cinza escuro & $15 \%$ a $25 \%$ \\
\hline
\end{tabular}

Adaptado de ROCHA, 1986 em TEIXEIRA et al, 2004

Portanto, o bege, o creme e o amarelo claro são as cores mais adequadas para o revestimento das paredes. No entanto, em cozinhas industriais, a cor mais indicada é o branco, em função da existência de materiais e equipamentos confeccionados em aço inox, que interferem no índice de reflexão, favorecendo a ocorrência de ambientes escuros (TEIXEIRA et al, 2004).

Quanto à localização, a UAN deve ser no térreo, voltada para o nascente (conforto térmico) e em bloco isolado (reduz contaminação e facilita futuras ampliações e adaptações). Quando não for possível a localização em bloco isolado, deve ser situada na esquina do prédio (TEIXEIRA et al, 2004).

A localização térrea facilita o acesso de fornecedores e comerciantes, remoção de lixo, supervisão dos trabalhos, redução de custos de implantação e manutenção, possibilitando fácil comunicação com o exterior e dispensando elevadores. Na impossibilidade da localização em andar térreo, sugere-se a instalação de elevadores e monta-cargas exclusivos para a UAN (ABERC, 1995).

Os arredores da UAN não devem oferecer risco às condições de higiene e sanidade, ou seja, área livre de lixo, fumaça, animais, insetos, objetos em desuso e roedores. As áreas circundantes ao prédio devem ser de fácil higiene e limpeza, com calçadas contornando as instalações de, no mínimo, 1 metro de largura, com declive para escoamento. O acesso deve ser direto e independente, não comum a outros usos. Instalar lâmpadas de sódio na área externa do prédio, afastada das portas, para reduzir a atração de insetos noturnos (ABERC, 1995).

Em relação à forma geométrica, a mais indicada é a retangular, desde que o comprimento não exceda mais de 1,5 a 2 vezes a largura, o que propicia melhor disposição dos equipamentos, tem a vantagem de evitar caminhadas supérfluas e evita conflitos de circulação, além de facilitar a supervisão das atividades (TEIXEIRA et al, 2004). 
A escolha do revestimento para o piso, assim como a sua aplicação, deve merecer atenção especial e corresponder às exigências técnicas, que variam conforme a natureza do trabalho a ser executado e o esforço a que serão submetidos os materiais aplicados. A carga estática não deve ser a única preocupação na escolha do piso. Devem ser consideradas: facilidade de higienização, características antiderrapante, resistência ao ataque de substâncias corrosivas, suportar tráfego intenso, impermeabilidade e cor, cujo índice de reflexão deve estar situado entre $15 \%$ e $30 \%$.

O piso deve ser de material que permita limpeza fácil e adequada. A aplicação do piso monolítico é um fator que favorece a higienização por não apresentar rejuntes, no entanto, quando molhados, tornam-se escorregadios. Já o piso cerâmico com característica antiderrapante necessita de rejunte, que é foco de umidade e proliferação de bactérias. Existem também pisos à base de teflon, que são antiácidos, antiderrapantes e podem ser aplicados com o mínimo de rejunte possível, porém fica impossibilitado seu uso devido ao alto custo de implantação. Assim, dentre as opções disponíveis, a cerâmica antiácida, antiderrapante, de alta resistência e baixa porosidade, não esmaltada, ainda é a melhor opção do mercado (SILVA FILHO, 1996).

O piso deve ter, ainda, um único nível, evitando os acidentes de trabalho e facilitando o deslocamento de carros; deve ter inclinação suficiente em direção aos ralos para não acumular água e os ralos devem ser sifonados, para impedir a entrada de insetos e roedores. A junção entre piso/ parede e parede/ teto deve ter raio de curvatura de $5 \mathrm{~cm}$ para facilitar a limpeza (TEIXEIRA et al, 2004).

A construção da edificação a ser utilizada na UAN deve ser feita em alvenaria com todo o reboco íntegro. O revestimento para as paredes deve ser de material liso, resistente e impermeável, e lavável em toda a sua extensão. No que se refere à cor, devem ter um índice de reflexão de 50\% a 75\% (TEIXEIRA et al, 2004).

Quando usados azulejos, devem ser colocados, no mínimo, com 2 metros de altura e os rejuntes devem ser impermeáveis. Os azulejos devem ficar no mesmo nível da parede, sem nenhum vão, pois são nesses vãos que se escondem os insetos.

Os tetos devem ser lisos, não devem ter brechas e rugosidades para não absorver gorduras e sujeiras diversas. Devem ser de fácil limpeza, resistentes à 
temperatura e impermeável ao vapor. Deve-se evitar forro falso para que não propicie a proliferação de insetos e outros animais. Outras características indispensáveis aos tetos é que não sejam combustíveis nem propagadores de incêndio e devem absorver os ruídos das diversas operações realizadas na cozinha (SILVA FILHO, 1996).

A altura do teto não pode ser muito alta, pois se torna difícil sua limpeza e higienização; porém, se for baixo demais, pode haver problemas com ventilação, distribuição de luz, etc. O pé direito para UAN de grande porte deve estar entre 3,6 a 4,5m de altura; para as de médio e pequeno porte, deve estar entre 3,0 a 3,6 m; para áreas administrativas, o pé direito pode ser de 2,4 a 3,0 m de altura (SILVA FILHO, 1996).

As portas de acesso principais devem ser amplas para permitir a passagem de equipamentos e trânsito de carros auxiliares sem comprometer a segurança. As portas internas devem ter visor para que as pessoas possam perceber o que se passa no ambiente contíguo e devem ser do tipo vaivém (SILVA FILHO, 1996).

As portas devem ser de madeira revestida de material lavável. Devem ainda ter largura e altura mínimas nunca inferiores a 1,00 e 2,00 m, respectivamente. Devem ter borracha de vedação na extremidade inferior, a fim de evitar a entrada de insetos e roedores (TEIXEIRA et al, 2004).

Na parte superior das paredes, devem ser localizadas as janelas, objetivando garantir o conforto térmico, já que o ar quente tende a se instalar nos níveis mais altos; a iluminação natural, uniformemente distribuída para evitar sombra e incidência dos raios solares diretamente sobre a superfície de trabalho; assim como corrente de ar sobre o fogão. As esquadrias devem ser móveis e laváveis, os vidros transparentes e lisos, para garantir melhor iluminação e higienização. A instalação de telas para evitar a entrada de insetos e pássaros também é importante (TEIXEIRA et al, 2004).

Como instalações, são consideradas todas as redes (água, esgoto, vapor, gás e elétrica) que proporcionam infra-estrutura à UAN. As tubulações devem ser pintadas nas cores indicadas pela autoridade competente em segurança e medicina do trabalho, para identificação e facilidade nos reparos: amarelo para inflamáveis, azul para vapor, verde para água e preto para esgoto. As tubulações externas 
facilitam a manutenção, mas as internas evitam que possíveis vazamentos possam contaminar os alimentos (TEIXEIRA et al, 2004).

Em UAN se usa grande quantidade de água fria e quente. Portanto, as redes devem ser bem dimensionadas para atender à demanda de consumo. Para efeito de dimensionamento de caixas d'água, a quantidade requerida para prever o consumo total de água é de 28 litros por refeição, sendo 20 litros de água fria e 8 de água quente (SILVA FILHO, 1996).

A rede mais problemática é a de esgoto, que deve ter algumas características especiais em relação aos esgotos comuns, como: evitar redes com muitos ramais, de preferência que vá direto para as caixas coletoras; construir todas as caixas de gordura fora do prédio; pontos de coleta de água de piso, através de grelhas especiais dotadas de bandejas coletoras e retentoras de resíduos e que bloqueiam também a entrada de insetos e roedores; e utilizar materiais resistentes a temperaturas e ácidos (SILVA FILHO, 1996).

A rede elétrica deve ser bem dimensionada e com todas as proteções necessárias. Para evitar acidentes, deve-se sempre usar os sistemas de aterramento de todos os equipamentos.

Os quadros de comando devem ficar estrategicamente bem localizados, com fácil acesso, de maneira a serem desligados nas emergências, sem atropelos. Devem ser embutidos para facilitar limpeza e higienização dos ambientes (SILVA FILHO, 1996).

Atenção especial deve ser dispensada à escolha das tomadas de força, que devem ser individualizadas para cada equipamento. Recomenda-se também que estas tomadas sejam do tipo blindado, para facilitar a higienização das paredes e evitar entrada de água na rede elétrica (TEIXEIRA et al, 2004).

Lixo é sobra de material não aproveitável no processo de produção e que retorna não consumido das bandejas, como restos alimentares, sobra na preparação e materiais descartáveis. O lixo orgânico deve ficar acondicionado em local fechado, isento de moscas, roedores e outros animais até ser recolhido, de preferência sob refrigeração, que bloqueia o crescimento e desenvolvimento das bactérias, inibindo a produção de gases e líquidos que causam odores desagradáveis, mau cheiro (SILVA FILHO, 1996). 
Os depósitos de lixo devem ter tampa para evitar o ingresso de insetos e contaminação das matérias-primas, do alimento e da água potável; devem estar revestidos internamente com saco plástico, de consistência resistente que, após estarem cheios, devem ser fechados e transportados para o devido lugar. O lixo não deve sair pelo mesmo local por onde entram as matérias-primas (SILVA FILHO, 1996).

Os banheiros devem ser separados por sexo e estar em bom estado de conservação, constituído de vaso sanitário, pia, mictório (masculino) e chuveiro para cada 20 funcionários, pias para lavar as mãos com torneiras de acionamento automático e armários individuais. As instalações sanitárias não devem se comunicar diretamente com a área de manipulação de alimentos ou refeitórios. Devem ser bem iluminadas, paredes e pisos de material liso, resistente, impermeável e de cores claras, portas com molas para fechamento automático e ventilação adequada com janelas teladas (SEBRAE, 2000 apud OLIVEIRA, 2003).

Complementando o planejamento da área física, assumem relevância os equipamentos, uma vez que sua localização define o lay-out das áreas da UAN. Esta localização deve atender ao fluxo racional das operações, permitir acesso fácil e limpeza adequada, evitando cruzamentos e retornos desnecessários, estrangulamentos das circulações e poluição sonora. Também influenciam a escolha dos equipamentos a natureza e a dimensão do estabelecimento (TEIXEIRA et al, 2004).

Todo equipamento e utensílio utilizados nos locais de manipulação de alimentos que possam entrar em contato com o alimento devem ser confeccionados de material que não transmita substâncias tóxicas, odores e sabores, que sejam não absorventes e resistentes à corrosão e capazes de suportar repetidas operações de limpeza e desinfecção (SILVA FILHO, 1996).

A estrutura física assume grande importância para a qualidade das refeições produzidas na UAN; porém, possui suas limitações e não deve ser um fator único a ser considerado. Deve ser pensado em conjunto com Boas Práticas de Fabricação e fluxogramas e processos adequados. 


\subsection{COMPOSIÇÃO DA ÁREA DA UAN}

A área da UAN deve ser planejada seguindo uma linha de produção o mais racional possível. Suas unidades operacionais devem obedecer a um fluxo coerente, evitando o cruzamento e retrocessos que tanto comprometem a produção das refeições (ABERC, 1995).

Cada área possui padrões, a seguir descritos.

\subsection{1 Área de aprovisionamento}

A área de aprovisionamento compreende as áreas de recepção e estocagem, sendo necessária uma área própria para o recebimento de mercadorias, que deve ser externa ao serviço de nutrição, dotada de plataforma anatômica coberta, de fácil acesso aos fornecedores, para descarga de gêneros alimentícios. Deverá ser provida de rampas, visando facilitar o transporte de cargas. O local para inspeção, pesagem e pré-higienização dos gêneros alimentícios deve constituir um prolongamento da plataforma de descarga, devendo ser aparelhada com balança para pesagem de mercadorias, carros para transporte e tanques ou calhas, para higienização das hortaliças antes do seu armazenamento (ABERC, 1995; MEZOMO, 1994; TEIXEIRA et al, 2004).

Durante o recebimento, o estoquista e o nutricionista deverão estar presentes para fiscalizar a quantidade e qualidade dos gêneros e produtos, e deverão fazer o controle utilizando-se de planilhas específicas para esse fim (PASSOS, 1982).

Deve haver tanques ou pias para pré-lavagem das frutas e hortaliças antes do seu armazenamento. A existência de esguicho de pressão é importante para auxiliar nestes procedimentos (ABERC, 1995).

$A$ área de estocagem é destinada à guarda de gêneros alimentícios e deve localizar-se junto à área de recepção e ser acessível à área de processamento, evitando transporte de gêneros a longas distâncias, assim como a circulação de pessoas estranhas à UAN. Deve ser constituída de despensas, para estocagem de gêneros de maior conservação à temperatura ambiente, e câmaras ou refrigeradores com controle de temperatura e unidade, para estocagem de gêneros perecíveis (TEIXEIRA et al, 2004). 


\subsubsection{Almoxarifado}

Área para armazenamento de alimentos e outros produtos à temperatura ambiente (almoxarifado ou estoque).

É a área destinada à estocagem de gêneros de maior conservação à temperatura ambiente.

A fim de garantir as condições ideais para conservação dos gêneros ali estocados e permitir um controle eficaz das mercadorias, o almoxarifado deverá apresentar (SILVA JR, 1995):

- porta única, larga e alta, simples ou em seções;

- borracha de vedação na parte inferior da porta;

- piso em material lavável e resistente;

- ausência de ralos para escoamento de água;

- boa iluminação, ventilação cruzada ou mecânica, que permita ampla circulação de ar entre as mercadorias;

- janelas e aberturas teladas;

- temperatura nunca superior a $27^{\circ} \mathrm{C}$;

- inexistência de tubulações de água e vapor;

- prateleiras para armazenamento localizadas a $30 \mathrm{~cm}$ do piso, com profundidade não superior a $45 \mathrm{~cm}$, preferencialmente moduladas, para permitir flexibilidade de novos arranjos;

- estrados fenestrados para sacarias, elevados do piso até $40 \mathrm{~cm}$, com pés protegidos com canoplas;

- locais distintos para armazenagem de produtos de limpeza e descartáveis;

- escada com patamar e rodízios;

- extintor de incêndio;

- protetor contra ratos no rodapé.

\subsubsection{2 Área para armazenamento de alimentos sob temperatura controlada}

Destina-se à estocagem de gêneros perecíveis em condições ideais de temperatura e umidade. Devido à grande diversificação das características dos 
alimentos utilizados, recomenda-se, no mínimo, a instalação de três câmaras frigoríficas ou geladeiras: uma com temperatura até $4^{\circ} \mathrm{C}$ e umidade relativa de $60 \%$ a $70 \%$ para conservação de carnes; outra com temperatura de $10^{\circ} \mathrm{C}$ e umidade de $80 \%$ para frutas e hortaliças e outra com até $8^{\circ} \mathrm{C}$ para laticínios e sobremesas (SILVA JR, 1995).

A necessidade de instalação de câmaras de congelamento deve ser analisada em função das facilidades de abastecimento, freqüência de utilização e quantidade do produto a ser adquirido.

As câmaras devem apresentar as seguintes características (SILVA JR, 1995):

- serem dotadas de antecâmara, para proteção térmica;

- revestimento de material lavável e resistente. Quando o revestimento for de azulejo, este nunca deverá ser aplicado do piso ao teto. O restante da parede deverá ser revestido com tinta látex ou epóxi;

- nível do piso igual ao da área externa, para facilitar o transporte de mercadorias pelos carros;

- inexistência de ralos internos, mesmo quando sifonados;

- serem dotadas de termômetro tipo mostrador, permitindo a leitura pelo lado externo;

- interruptor de segurança, localizado na parte externa da unidade refrigerada, com lâmpada-piloto indicativa da condição "ligado" e "desligado";

- serem dotadas de prateleiras em aço inox, moduladas, para permitir flexibilidade de novos arranjos;

- no caso de câmaras de carne, deverão ser dotadas de bandejas de alumínio ou plástico não poroso, para guardar miúdos, carne moída, etc. Se houver possibilidade de comprar carnes em peças grandes, adquirir também os gancheiros;

- porta hermética, revestida em aço inox, ferragens cromadas e dispositivos de segurança, permitindo abertura por dentro.

\subsection{2 Área de processamento}

A área de processamento é subdividida nas unidades operacionais de prépreparo, cocção, distribuição das preparações e higienização dos utensílios. Nos 
hospitais, as cozinhas dietéticas complementam esta área. Com exceção da higienização dos utensílios, não é necessário que esta subdivisão seja feita através de paredes completas, pois elas podem prejudicar a iluminação e ventilação e dificultar a supervisão das operações ali realizadas (TEIXEIRA et al, 2004).

\subsubsection{1 Área de preparações prévias (pré-preparo)}

Neste local são realizadas as operações preliminares de confecção, podendo a área ser dividida em:

- pré-preparo de carnes, aves e peixes: necessária a qualquer unidade, independente do número de refeições. Deve dispor de uma bancada com tampo de material adequado para manipulação das carnes. Deve contar ainda com um balcão com cuba, onde devem ser dispostos os equipamentos necessários aos trabalhos aí realizados;

- pré-preparo de hortaliças e frutas: deve ser dotada de bancada com tampo de aço inox, cubas, mesas de altileno e local para dispor todos os equipamentos utilizados nas operações;

- pré-preparo de massas e sobremesas: deve dispor de bancada com tampo de aço inox, cubas, mesas de altileno, tampo de mármore e local para dispor os equipamentos utilizados nesta área.

Para preparação de refeições como lanches, desjejum e café, devem ser previstas áreas específicas para estes fins. O número de cubas e seu dimensionamento, assim como o tamanho dos balcões da área de processamento, estão relacionados ao número de refeições, padrão do cardápio, sistema e modalidade de distribuição.

É importante que as áreas de pré-preparo disponham de pia exclusiva para higienização das mãos dos manipuladores, dotada de torneira de acionamento automático.

\subsubsection{2 Área para cocção}

Deve se situar entre a área de pré-preparo e a expedição de equipamentos necessários a esta fase, organizados segundo um fluxo racional e balcões de apoio específicos aos tipos de equipamentos (ABERC, 1995). 
É importante que esta área disponha de uma pia exclusiva para higienização das mãos dos manipuladores, dotada de torneira (o ideal é que seja de acionamento automático), água corrente, sabão líquido, escova para unhas, anti-séptico, toalhas de papel não recicladas ou outro sistema adequado de secagem (ABERC, 1995).

A área de cocção compreende a Cozinha geral (preparo da dieta geral, que atende à grande maioria dos clientes, incluindo os funcionários e os pacientes sem necessidades nutricionais diferenciadas), Cozinha dietética (confecção das dietas especiais, oferecidas aos pacientes que requerem alterações na composição ou forma de preparo da dieta normal) e Setor de preparo de sondas (preparo e distribuição de sondas enterais e nasogástricas) (MEZOMO, 1994).

\subsection{3 Área de distribuição}

O Setor de Distribuição de Alimentos é destinado ao porcionamento e distribuição de refeições aos pacientes, funcionários, acompanhantes e visitantes. Tem delimitação relacionada à modalidade ou tipo de distribuição (TEIXEIRA et al, 2004).

As refeições saem da área de cocção diretamente para a copa de distribuição, em carros transporte ou de "pass through", para abastecimento do balcão de distribuição. Nestes casos, essa área será mínima, apenas com o espaço necessário ao abastecimento dos carros (SILVA JR, 1995).

\subsubsection{Refeitório}

É o local onde os clientes fazem suas refeições. Deve ter espaço para mesas e cadeiras com perfeita circulação, lavatório e cafeteiras (SILVA JR, 1995).

\subsection{4 Área para higienização}

\subsubsection{1 Área para higienização dos utensílios utilizados no processamento}

Recomenda-se que esta área seja delimitada por parede completa, porém sem prejuízo de iluminação e ventilação. É importante contar com um sistema de drenagem bem dimensionado, local para dispor os utensílios que aguardam a 
higienização, cubas profundas, bem como local para guarda do material após a higienização (SILVA JR, 1995).

A higiene dos utensílios e equipamentos é uma atividade essencial para garantia da qualidade sanitária dos alimentos. Os riscos de toxinfecções alimentares em UAN's são constantes. Um dos fatores de risco é a higienização incorreta de utensílios e equipamentos utilizados no processamento das refeições, principalmente os equipamentos utilizados no preparo dos alimentos que são consumidos crus (CHESCA et al, 2003).

\subsubsection{2 Área para higienização de bandejas}

Esta área deve ser adjacente ao restaurante, comunicando-se com este por meio de guichê para recepção do material usado. O lay-out desta área deve estar de acordo com o sistema eleito para higienização de utensílios. Deve haver, também, instalação para guarda do material após a higienização (ABERC, 1995).

\subsubsection{3 Área para higienização de carros}

Deve haver nas UAN's uma área específica para higienização de carros que transportam as refeições prontas e carros auxiliares de transporte de alimentos crus, afastada da área de produção. Deve contar com recursos necessários para uma boa higienização, como água tratada, esguicho de água de pressão e produtos de lavagem e sanitização.

\subsubsection{4 Área para higienização do material de limpeza}

Área para guarda de objetos utilizados na higienização da unidade, como vassouras, rodos, esfregões, panos de chão, baldes, etc. Deve dispor de uma cuba para limpeza dos materiais utilizados.

Em todas as áreas de processamento de alimentos, é preciso dar ênfase especial à faculdade de limpeza completa e todas as superfícies e equipamentos devem poder ser limpos com o mínimo de esforço. 


\subsubsection{Sala de administração}

Deve ser situada em local que facilite a supervisão das operações do processamento das refeições. A colocação de piso em nível mais elevado que o da área em que está situado, bem como um visor em toda a extensão da sala, a partir de um metro do piso, facilitará a visão do ambiente a ser supervisionado (SILVA JR, 1995).

\subsection{6 Área para instalações sanitárias e vestiários}

Devido à importância da higiene corporal na preservação do grau de higiene da alimentação, o correto é que as instalações sanitárias sejam exclusivas para a equipe que trabalha na UAN. Estas devem ser inseridas de forma isolada, nunca se comunicando diretamente com as demais unidades operacionais, sobretudo com as áreas de processamento ou distribuição (SILVA JR, 1995).

As instalações devem contar com armários, pias com sabão líquido, substâncias anti-sépticas e toalha de papel e chuveiros fechados, com boxe individual. Estas instalações devem ser separadas para ambos os sexos, sendo 1 para cada 20 funcionários. Devem estar providas com água corrente e conectadas à rede de esgoto ou com fossa aprovada. O piso deve ser de material cerâmico e as portas com molas e aberturas teladas, em bom estado de conservação. É recomendável a utilização de recipientes com sacos plásticos e tampas, de preferência com pedal, para o descarte do papel higiênico usado (ABERC, 1995).

\subsection{7 Área para guarda de recipientes}

É importante a existência de uma área externa destinada à guarda de caixotes, latas, vidros e outras embalagens vazias, retornáveis ou não, para serem armazenados até que sejam removidas, vendidas, devolvidas ao fornecedor ou descartadas (ABERC, 1995).

\subsubsection{Destino do lixo}

Área destinada ao armazenamento diário de lixo. Deve ser localizada em ponto que facilite a sua remoção, ser toda revestida de material lavável e dotada de 
esguicho de pressão com água fria e quente para limpeza dos coletores. Quando possível, este local deve ser substituído por unidade refrigerada, como já citado anteriormente, para retardar a proliferação de bactérias mesófilas que contaminam o lixo, facilitando a sua putrificação e fermentação e produzindo odores desagradáveis (SILVA JR, 1995).

\subsection{9 Área para guarda de recipientes de gás}

Tem seu dimensionamento relacionado ao consumo de gás. Deve ser localizada na parte externa, em ponto estratégico. De acordo com as diretrizes da ABNT (Associação Brasileira de Normas Técnicas), esta área deve ser delimitada com cerca, tela, grade vazada ou outro processo construtivo para assegurar exclusividade à área, evitar a transposição de pessoas estranhas e permitir ventilação (ABERC, 1995). 


\subsection{DIMENSIONAMENTO}

Uma complexa etapa do planejamento é a determinação da área de uma UAN por envolver uma série de variáveis, como número de refeições, padrão dos cardápios, modalidade e sistema de distribuição e política de compras e de abastecimento (TEIXEIRA et al, 2004).

Para determinar a área de uma UAN, vários são os índices empregados. De acordo com Mezomo (1994), a área necessária para hospitais de até 200 leitos é encontrada da seguinte forma,

a) $1,8 \mathrm{~m}^{2}$ por leito para a UAN com distribuição descentralizada, cabendo aproximadamente $20 \%$ à recepção, 50 \% ao preparo e cocção e 30 \% para as demais dependências.

b) 2,0 $\mathrm{m}^{2}$ por leito para a UAN com distribuição centralizada, cabendo aproximadamente 20 \% à recepção e estocagem, $45 \%$ ao preparo e cocção e 35 \% para as demais dependências.

No tipo de distribuição centralizado, a refeição é preparada, distribuída, porcionada e identificada na própria área de produção. No sistema descentralizado, a refeição é preparada na área de produção, sendo que os alimentos são acondicionados em carros térmicos que os transportam para as copas das unidades de internação, onde se processam o porcionamento, a identificação e a distribuição das refeições. O tipo misto tem parte da distribuição centralizada e parte descentralizada (MEZOMO, 2004).

Um outro índice utilizado é o de Passos (1982), que dimensiona a área da UAN partindo também do número de leitos do hospital, e recomenda:

a) até 60 leitos: $1,00 \mathrm{~m}^{2}$ por leito

b) de 61 a 150 leitos: 0,75 a 0,9 $\mathrm{m}^{2}$ por leito

c) mais de 150 leitos: estudo especial

O Ministério da Saúde citado em Passos (1982) recomenda:

a) até 50 leitos: $1,50 \mathrm{~m}^{2}$ por leito 
b) de 51 a 150 leitos: $1,20 \mathrm{~m}^{2}$ por leito, reservando-se sempre a área mínima de $75 \mathrm{~m}^{2}$

c) mais de 150 leitos: $1,00 \mathrm{~m}^{2}$ por leito, observando-se a área mínima de $180 \mathrm{~m}^{2}$ Já Silva Filho (1996), propõe que a determinação da área física seja calculada em função do número de refeições servidas pela UAN em uma única etapa. Basta multiplicar o número de refeições por um coeficiente, conforme o quadro abaixo:

Quadro 3: Área Total (exceto o refeitório e anexos)

\begin{tabular}{|c|c|}
\hline $\mathrm{N}^{\circ}$ de refeições & Coeficientes \\
\hline 100 & 0,9 \\
\hline 150 & 0,8 \\
\hline 200 & 0,7 \\
\hline 250 & 0,6 \\
\hline 300 & 0,5 \\
\hline 400 & 0,4 \\
\hline 500 & 0,35 \\
\hline 600 & 0,35 \\
\hline 700 & 0,30 \\
\hline 800 & 0,30 \\
\hline 900 & 0,30 \\
\hline 1000 & 0,30 \\
\hline 1500 & 0,28 \\
\hline 2000 & 0,26 \\
\hline 3000 & 0,24 \\
\hline 5000 & 0,20 \\
\hline
\end{tabular}

Área da UAN em $\mathrm{m}^{2}$ = número de refeições $\mathrm{x}$ coeficiente

Os índices propostos por Mezomo (2004) e Passos (1982) levam em consideração o número de leitos do hospital. No entanto, em se tratando de um hospital com grande número de funcionários e estagiários, como um hospital 
universitário, esse índice subestimaria a área necessária para atender a demanda. Nesse caso, há a opção do índice de Silva Filho (1996), que propõe que a área da UAN seja determinada com base no número de refeições preparadas.

\subsection{ERGONOMIA DO TRABALHO}

No projeto da área física, devem ser observados alguns fatores relativos a ergonomia, a fim de evitar o estresse, reduzir o cansaço e as doenças entre os trabalhadores. Habitualmente, na fase de concepção do projeto não se leva em conta as peculiaridades do ser e da condição humana.

A ergonomia visa adaptar o trabalho ao homem, abrangendo não apenas as máquinas e equipamentos, mas toda a situação em que ocorre o relacionamento do homem com o trabalho que o mesmo executa (BRASIL, 1994). Condições inadequadas de trabalho com problemas de ambiente, equipamentos e processos acabam levando a insatisfações, cansaço excessivo, queda de produtividade, doenças e acidentes de trabalho. Tais condições interferem diretamente na qualidade do produto final.

Antes da concepção do projeto é indicado fazer uma análise ergonômica e verificar quais fatores influenciam a carga de trabalho, ou seja, que podem levar a sobrecarga ou subcarga do mesmo. Em seguida, procurar-se-á adequá-las à capacidade dos funcionários, com o objetivo de evitar essa variação na carga de trabalho.

É aconselhável a participação de um ergonomista na fase de concepção do projeto; ele fará a análise ergonômica baseada na atividade real desenvolvida pelos trabalhadores e se valerá de dados antropométricos para o mais adequado dimensionamento de áreas, altura de bancadas entre outros.

É indispensável conversar com os funcionários, já que é impossível avaliar a carga de trabalho apenas pelas exigências da tarefa. É com os funcionários que se vai delimitar o que analisar, bem como as possibilidades de soluções que thes sejam mais satisfatórias (BRASIL, 1994). Os funcionários respondem às boas condições de trabalho, sentindo maior orgulho do ambiente do trabalho e de si mesmas.

Ambientes de trabalho inadequados podem ser a causa de doenças entre os trabalhadores, como exemplo: dores no pescoço, ombros e na região inferior das 
costas devido a altura inadequada de bancadas; dores nas pernas devido a larga permanência de pé. O cansaço e o risco destes problemas são reduzidos quando o trabalho é realizado evitando-se as posturas forçadas. Deve-se avaliar em quais tarefas é conveniente estar de pé e em quais é melhor estar sentado (BRASIL, 2001).

\subsection{SEGURANÇA ALIMENTAR}

Segurança Alimentar e Nutricional (SAN) é a realização do direito de todos ao acesso regular e permanente a alimentos de qualidade, em quantidade suficiente, sem comprometer o acesso a outras necessidades essenciais, tendo como base práticas alimentares promotoras da saúde, que respeitem a diversidade cultural e que sejam social, econômica e ambientalmente sustentáveis (Consea, 2004).

A SAN abrange dois componentes:

1. Alimentar: relacionado à produção, disponibilidade, comercialização, acesso e consumo do alimento saudável.

2. Nutricional: relacionado às práticas alimentares (onde, como e quando nos alimentamos, o que escolhemos, como preparamos e o que consumimos) e a utilização biológica dos alimentos (indicadores antropométricos, bioquímicos, etc.) contemplando todas as fases do ciclo de vida, estendendo a grupos institucionalizados (creches, escolas, asilos, presídios, etc.).

Em UAN's, uma preocupação freqüente deve existir em relação à segurança alimentar, já que há risco de ocorrência de doenças veiculadas por alimentos. O componente nutricional da SA inclui a garantia da qualidade higiênico-sanitária, consistindo em garantir à clientela condições de acesso a alimentos seguros. Esse aspecto se torna ainda mais relevante em uma UAN hospitalar, que atende indivíduos enfermos e debilitados.

A área física das UAN's constitui um ponto importante no processo de contaminação dos alimentos, já que possui umidade, temperatura e matéria-prima adequadas para o desenvolvimento de microorganismos. Conseqüentemente, as condições do ambiente são determinantes da qualidade final das refeições produzidas. 


\section{MATERIAL E MÉTODO}

O presente trabalho é um estudo de caso descritivo. A coleta de dados ocorreu durante os meses de outubro de 2005 a janeiro de 2006, em que foram realizadas observações, avaliação da estrutura física, análise dos dados coletados, comparação com dados coletados anteriormente e propostas de melhorias.

Fez-se uma revisão de literatura com a finalidade de conhecer todos os parâmetros relacionados à estrutura física de UAN's, especialmente as UAN's hospitalares, descrevendo-se, assim, as condições ideais.

A avaliação da estrutura física da UAN foi realizada por meio da aplicação do check list elaborado pela Agência Nacional de Vigilância Sanitária - ANVISA, de acordo com a Resolução - RDC n² 275, de 21 de outubro de 2002 (Anexo 1), que abrange todos os procedimentos a serem adotados por empresas produtoras/ industrializadoras de alimentos. Foram avaliados aspectos relacionados com a edificação e instalações; equipamentos, móveis e utensílios; manipuladores; produção e transporte do alimento e documentação.

As medidas da estrutura física da UAN foram aferidas a partir da planta obtida junto ao departamento de engenharia do HUB, com um dos arquitetos responsáveis. As aferições de ruído, temperatura e umidade foram realizadas pelo engenheiro do trabalho da Universidade de Brasília.

Após a avaliação, foram feitas análises dos resultados encontrados, com discussão de cada item da estrutura física da UAN e impacto das irregularidades na segurança dos alimentos.

Posteriormente, a avaliação da estrutura física atual foi comparada com avaliação realizada anteriormente, analisando-se as mudanças acontecidas na UAN, se foram favoráveis para a melhoria da qualidade higiênico-sanitária da UAN.

Por fim, propostas foram feitas para corrigir as principais falhas diagnosticadas. 


\section{RESULTADOS E DISCUSSÃO}

Este capítulo traz, inicialmente, a apresentação da instituição estudada e sua UAN. Em seguida, faz-se a análise da estrutura física da UAN, abordando todos os aspectos previstos pela ANVISA: edificação e instalações; equipamentos, móveis e utensílios; manipuladores; produção e transporte do alimento e documentação.

Após esta etapa, é feita uma comparação da estrutura atual com uma avaliação realizada anteriormente (2003), a fim de conhecer as mudanças acontecidas na UAN. Por fim, são feitas propostas para corrigir as principais falhas diagnosticadas.

\subsection{IDENTIFICAÇÃO DO LOCAL}

O Hospital Universitário de Brasília (HUB) é uma instituição pública, de médio porte, vinculada à Universidade de Brasília (UnB). Teve seu funcionamento autorizado pelo Decreto n. 70.178 de 21 de fevereiro de 1972, apresentando como entidade mantenedora inicial o Instituto de Pensão e Aposentadoria dos Servidores do Estado (IPASE). Foi inaugurado, oficialmente, em agosto de 1972, pelo então Presidente da República, General Emílio Médici, recebendo o nome de Hospital dos Servidores da União (HSU) e, logo após, passou a se chamar Hospital do Distrito Federal Presidente Médici (HDFPM).

Ainda na década de 70, com a extinção do IPASE, o hospital passou a fazer parte do Instituto Nacional de Assistência Médica da Previdência Social (INAMPS). No início dos anos 80, passou a ser o Hospital de Ensino da Universidade de Brasília e recebeu o nome de Hospital Docente-Assistencial (HDA). Em 1990, foi cedido em comodato à UnB em ato assinado pelo Presidente Fernando Collor e passou a se chamar Hospital Universitário de Brasília (HUB).

Desde então, o HUB é administrado pela Fundação Universidade de Brasília (FUB), sendo subsidiada financeiramente por esta, pelo Sistema Único de Saúde (SUS) e pelo Ministério da Saúde (MS). Os atendimentos são realizados pelo SUS e por alguns convênios de saúde. 
O HUB conta atualmente com 289 leitos, 121 salas de atendimento ambulatorial e $41.170 \mathrm{~m}^{2}$ de área construída. Seu Corpo Clínico é formado por diversos profissionais da área de saúde, como médicos, nutricionistas, enfermeiros, farmacêuticos, psicólogos, entre outros; professores da UnB, servidores do Ministério da Saúde e profissionais contratados.

O HUB apresenta, atualmente, 33 especialidades médicas, e um atendimento ambulatorial, em média, de 28.000 consultas e procedimentos diversos/mês, com cerca de 900 internações. O Centro de Pronto Atendimento realiza, aproximadamente, 8.000 consultas e/ou procedimentos. No total, o HUB faz 36.000 atendimentos a cada mês.

Esses números demonstram a importância da instituição na atenção à saúde no DF, sobretudo por estar dentro do SUS como responsável pelos atendimentos classificados como secundários e caracterizados pela alta complexidade de procedimentos. É o único hospital universitário do DF, que recebe alunos de várias instituições para qualificação profissional, em todos os níveis (médio, superior e profissionalizante).

\subsection{A UNIDADE DE ALIMENTAÇÃO E NUTRIÇÃO (UAN)}

A UAN do HUB consiste em um serviço próprio e, como aquele, é subsidiado pela FUB, SUS, MS e convênios com empresas públicas e privadas. Possui recursos humanos e administração própria e exerce atividades-fim com o objetivo principal de fornecer alimentação adequada e nutricionalmente equilibrada a pacientes, seus acompanhantes e funcionários, de forma a auxiliar na recuperação da saúde dos pacientes e promover e/ou manter a saúde. Compartilha, portanto, do objetivo final do hospital.

A UAN elabora e oferece diariamente refeições para pacientes, acompanhantes, funcionários do hospital, residentes, internos do curso de medicina e estagiários. São fornecidas diariamente aos pacientes 6 refeições, sendo: desjejum, colação, almoço, merenda, jantar e ceia. Aos acompanhantes são oferecidos apenas desjejum, almoço e jantar, com exceção dos idosos, gestantes e lactantes, que recebem também as três refeições intermediárias. Os funcionários, 
residentes, internos e estagiários recebem desjejum, almoço e ceia conforme a escala de trabalho.

A UAN abarca 4 setores: Centro de Produção de Refeições Normais (Cozinha Geral), Centro de Produção de Refeições Especiais (Cozinha Dietética), Confeitaria e Área de Colação. A Cozinha Geral fornece refeições aos funcionários, estagiários, residentes, internos, acompanhantes e pacientes que não apresentam restrições alimentares. As refeições dos pacientes que necessitam de alimentação diferenciada são produzidas na Cozinha Dietética. Na Confeitaria são preparados doces, pães, roscas, sobremesas em geral, bolos e tortas. Por fim, a área de Colação elabora mingaus, sucos, vitaminas e prepara as frutas.

O cardápio oferecido pela UAN é de padrão trivial, caracterizado por preparações pouco elaboradas e de custo baixo. Contudo, em alguns dias, são disponibilizadas preparações mais complexas, como lasanha ou strogonoff, que, no entanto, são realizados com ingredientes triviais. O strogonoff de carne, por exemplo, é preparado com coxão mole, e não com filet mignon.

No Centro de Produção de Refeições Normais, são elaborados cardápios cíclicos de período de 28 dias, compostos por um prato principal, dois acompanhamentos (arroz e feijão), uma salada, uma guarnição, um refresco e uma sobremesa.

Já no Centro de Produção de Refeições Especiais, o cardápio cíclico tem como período 14 dias e são servidos um prato principal, duas guarnições (um vegetal A e um vegetal B), dois acompanhamentos (arroz e feijão), salada (exceto para dieta branda) e sobremesa.

O sistema de distribuição das refeições da unidade é do tipo centralizada, tanto para a Cozinha Geral quanto para a Cozinha Dietética. Todas as refeições são porcionadas nas legumeiras e acondicionadas em área contínua à de produção, não existindo uma copa para tanto.

A modalidade de atendimento para pacientes e acompanhantes é do tipo empratado, realizado através de porcionamento. Tanto na cozinha dietética quanto na cozinha geral, as refeições são porcionadas pelos funcionários da UAN. 
No refeitório, a modalidade de atendimento é do tipo cafeteria, sendo as preparações distribuídas em um balcão térmico e porcionadas pelos funcionários encarregados pelo balcão de distribuição.

A quantidade de refeições produzidas varia de acordo com o número de pacientes, acompanhantes e funcionários presentes. O número de funcionários que recebem alimentação no hospital varia conforme os dias da semana e com a escala de trabalho destes. Os funcionários da UAN têm o direito de realizar as refeições em horário anterior aos demais funcionários do hospital, durante seu horário de serviço. Os demais funcionários podem realizar o desjejum e almoço quando em plantão diurno e o jantar quando em plantão noturno. Somente têm direito à alimentação todos os funcionários com jornada de trabalho de 12 horas e os funcionários contratados com carga de trabalho igual ou superior a 8 horas diárias. Além disso, os funcionários responsáveis pela higienização, lavanderia e segurança, independente da jornada de trabalho, têm direito ao desjejum.

A UAN fornece também lanches para todos os funcionários que trabalham em áreas fechadas (Centros Cirúrgicos, Central de Material Esterilizado, Centro de Terapia Intensiva, Berçário), Lavanderia, Higienização, Banco de Leite, Programas Ambulatoriais (idosos, diabéticos, alcoolismo, psiquiatria infantil, endoscopia), Serviço Social, além de refeições não programadas.

As tabelas abaixo demonstram a média de refeições distribuídas no refeitório e para as clínicas durante o mês de novembro de 2005 e a estatística do ano de 2004.

Tabela 1: Número médio de refeições em novembro/ 2005

\begin{tabular}{|l|c|c|c|c|c|}
\hline Refeições & \multicolumn{2}{|c|}{ Refeitórios } & \multicolumn{2}{c|}{ Clínicas } & Acompanhantes \\
\hline & Total mensal & Média diária & Total mensal & Média diária & Média diária \\
\hline Desjejum & 5.940 & 198 & 6.662 & 222 & 87 \\
\hline Colação & --- & --- & 4.237 & 141 & 12 \\
\hline Almoço & 9.272 & 310 & 7.229 & 241 & 86 \\
\hline Merenda & 11.308 & 377 & 5.394 & 180 & 10 \\
\hline Jantar & 860 & 29 & 6.392 & 213 & 84 \\
\hline Ceia & 2.866 & 96 & 4.958 & 165 & 12 \\
\hline TOTAL & $\mathbf{3 0 . 2 4 6}$ & $\mathbf{9 7 6}$ & $\mathbf{3 4 . 8 7 2}$ & $\mathbf{1 . 1 6 2}$ & $\mathbf{2 9 1}$ \\
\hline
\end{tabular}


Vale também ressaltar que o número de refeições é cerca de 3 vezes maior nos dias de semana em relação aos finais de semana. Além disso, o número é menor nos meses de férias e recessos de funcionários, alunos e estagiários (dezembro, janeiro, fevereiro e julho).

Em 2004, segundo o Resumo Anual elaborado pelo Setor de Estatística do HUB, foram servidas um total de 290.961 refeições no Refeitório e 357.659 nas Clínicas (Tabela 2), preparadas na Unidade de Alimentação e Nutrição do Hospital.

Tabela 2: Refeições servidas no Refeitório e Clínicas do Hospital Universitário de Brasília (HUB) no ano de 2004.

\section{REFEIÇÕES SERVIDAS}

\begin{tabular}{lccc}
\hline \multicolumn{3}{c}{ REFEITÓRIO } \\
\hline \multicolumn{1}{c}{ Refeição } & $\mathbf{1}^{\mathbf{0}}$ semestre & $\mathbf{2}^{\mathbf{0}}$ semestre & Total ano 2004 \\
\hline Desjejum & 28.322 & 27.192 & 55.514 \\
Almoço & 55.180 & 52.755 & 107.935 \\
Merenda & 37.136 & 44.048 & 81.184 \\
Jantar & 7.570 & 4.925 & 12.495 \\
Ceia das 22h & 16.923 & 16.910 & 33.833 \\
\hline TOTAL & $\mathbf{1 4 5 . 1 3 1}$ & $\mathbf{1 4 5 . 8 3 0}$ & $\mathbf{2 9 0 . 9 6 1}$ \\
\hline
\end{tabular}

\section{CLÍNICAS}

\begin{tabular}{lccc}
\hline \multicolumn{1}{c}{ Refeição } & $\mathbf{1}^{\mathbf{0}}$ semestre & $\mathbf{2}^{\mathbf{0}}$ semestre & Total ano 2004 \\
\hline Desjejum & 37.564 & 34.223 & 71.787 \\
Colação & 25.330 & 22.421 & 47.751 \\
Almoço & 32.296 & 35.515 & 67.811 \\
Merenda & 32.698 & 22.191 & 54.889 \\
Jantar & 30.224 & 31.899 & 62.123 \\
Ceia das 22h & 30.383 & 22.915 & 53.298 \\
TOTAL & $\mathbf{1 8 8 . 4 9 5}$ & $\mathbf{1 6 9 . 1 6 4}$ & $\mathbf{3 5 7 . 6 5 9}$
\end{tabular}

Fonte: Setor de Estatística do Hospital Universitário de Brasília (HUB). Resumo Anual de 2004. 
No mesmo ano, foram gastos $\mathrm{R} \$ 960.636,68$ na compra de insumos, incluindo gêneros alimentícios, material de limpeza, descartáveis e fórmulas especiais, como demonstra a Tabela 3.

Tabela 3: Gasto semestral e anual, em reais, relativos à compra de insumos para a UAN do Hospital Universitário de Brasília (HUB) em 2004

\begin{tabular}{lccc}
\hline \multicolumn{1}{c}{ PRODUTOS } & $\mathbf{1}^{\mathbf{0}}$ SEMESTRE & $\mathbf{2}^{\mathbf{0}}$ SEMESTRE & TOTAL ANO 2004 \\
\hline Carnes & $119.737,06$ & $120.047,35$ & $239.784,41$ \\
Hortifrutas & $80.623,58$ & $70.781,95$ & $151.405,53$ \\
Leite & $34.666,70$ & $30.620,54$ & $65.287,24$ \\
Suco & $24.535,70$ & $26.805,00$ & $51.340,70$ \\
Gêneros para & $31.352,86$ & $18.472,20$ & $49.825,06$ \\
panificação & $2.069,50$ & $7.217,34$ & $9.286,84$ \\
Polpa de fruta & & & $183.232,46$ \\
Gêneros Alimentícios & $95.818,41$ & $87.414,05$ & \\
semi-perecíveis & $35.827,66$ & $19.125,43$ & $54.953,09$ \\
Descartáveis & $13.660,88$ & $18.373,76$ & $32.034,64$ \\
Material de limpeza & $47.436,97$ & $76.049,74$ & $123.486,71$ \\
Fórmulas Especiais & $\mathbf{4 8 5 . 7 2 9 , 3 2}$ & $\mathbf{4 7 4 . 9 0 7 , 3 6}$ & $\mathbf{9 6 0 . 6 3 6 , 6 8}$ \\
\hline \multicolumn{1}{c}{ TOTAL } & & & \\
\hline
\end{tabular}

Fonte: Setor de Estatística do Hospital Universitário de Brasília (HUB). Resumo Anual de 2004. 


\subsection{ANÁLISE DA ESTRUTURA FÍSICA DA UAN}

Todos os itens da estrutura física da UAN foram avaliados com base no check-list de verificação das Boas Práticas de Fabricação em Estabelecimentos Produtores/industrializadores de Alimentos da ANVISA e com base nas recomendações atuais.

A avaliação da área física da UAN descrita neste trabalho aponta uma série de inadequações que representam riscos de contaminação alimentar, e podem comprometer a qualidade e segurança do produto final.

\subsubsection{Localização}

A UAN está localizada no térreo, porém, não é um bloco isolado, o que dificulta futuras ampliações, adaptações e controle de pragas, além de prejudicar a segurança do prédio, pelo fato da UAN possuir encanamentos de gás e vapor. E também não é na esquina do prédio. A localização térrea tem a vantagem de facilitar o acesso de fornecedores e comerciantes, remoção de lixo, redução de custos de implantação e manutenção por dispensar instalação de elevadores, tem fácil comunicação com o exterior e a detecção de defeitos nas tubulações é facilitada. (TEIXEIRA et al, 2004).

A área externa à UAN é pavimentada em toda a sua extensão, com piso de alvenaria e parede de pedra. Apenas a área de acesso externo possui área verde. As caixas de gordura são localizadas nessa área, com tampas lacradas, sendo abertas somente para manutenção e limpeza pelo setor encarregado. Medidas corretivas são adotadas na UAN, como dedetização periódica por empresa especializada. A aplicação das POP's neste setor, associada com medidas como borrachas de vedação nas portas vêm contribuindo para a redução de insetos e roedores para o interior da UAN. No entanto, ainda há necessidade de outras medidas preventivas, como manutenção da limpeza de toda a área externa do hospital, que encontra-se precária. 


\subsubsection{Forma geométrica}

A forma geométrica da UAN é retangular, o que propicia melhor disposição dos equipamentos, tem a vantagem de evitar caminhadas desnecessárias e evita conflitos de fluxo, além de facilitar a supervisão das atividades (TEIXEIRA, et al 2004). Porém, o comprimento total a é de $46,6 \mathrm{~m}$, sendo cerca de 3,3 vezes maior do que a largura, o que não é adequado, já que o recomendado é que o comprimento não exceda mais de 1,5 a 2 vezes a largura.

\subsubsection{Piso}

O observado no piso da referida UAN diverge do recomendado. Apesar do revestimento de cerâmica, material resistente, este apresenta vários ladrilhos quebrados, o que proporciona acúmulo de água e restos de alimentos nas rachaduras e buracos, tornando o piso mais escorregadio e propício a acidentes. Isso é ainda mais importante se considerarmos que o piso não se encontra sempre seco em todas as áreas, pois é higienizado 4 vezes ao dia, com falhas na secagem.

$\mathrm{Na}$ área de preparo, o piso não apresenta um nível único, o que contribui para aumentar o risco de acidentes, além de não ter inclinação adequada em direção aos ralos, dificultando o escoamento e aumentando o trabalho dos funcionários que, muitas vezes, têm que puxar a água com rodo.

Há ainda um agravante em relação ao piso, que são os rejuntes de aproximadamente $1 \mathrm{~cm}$ de largura que, por serem porosos, dificultam a higienização e facilitam a proliferação de microrganismos. Além disso, a cerâmica apresenta dimensões pequenas $(12 \mathrm{~cm} \times 24 \mathrm{~cm})$, contribuindo para aumentar a área de rejuntes.

Além disso, não há ralos sifonados colocados em locais adequados de forma a facilitar o escoamento e proteger contra a entrada de baratas e roedores.

Em relação à cor, a literatura recomenda revestimento de piso com índice de reflexão de $15 \% 30 \%$, que corresponde às cores preta, cinza, marrom, azul escuro e verde escuro. No entanto, considera-se que revestimento de piso com este índice de reflexão não favorece a identificação de sujidade, prejudicando a higienização, 
além de escurecer o ambiente. Por isso, considerou-se adequado o revestimento de cor clara (bege) presente na UAN.

\subsubsection{Paredes}

As paredes são revestidas por azulejos, material de fácil higienização, porém facilmente quebráveis em virtude do impacto dos carros de transporte. Foi observado que vários deles encontram-se em mau estado de conservação, com falhas, rachaduras e umidade, que propiciam a proliferação microbiológica e de pragas. Em vista disso, foram substituídos os azulejos quebrados e colocados novos onde eles não mais existiam.

Observa-se a presença de cantoneiras nas paredes, o que colabora com preservação das paredes. Não há ângulos abaulados entre as paredes e o piso e entre as paredes e o teto, o que permite o acúmulo de poeira e sujidades e dificulta a higienização.

\subsubsection{Teto}

O teto encontra-se em mau estado de conservação, apresentando umidade e mofo. O pé direito é de 4,28 m, superior ao recomendado (3,0-3,6 m para UAN de médio porte) e há muitas tubulações (elétrica, hidráulica, vapor e exaustão) expostas, o que mascara a cor clara do teto, dificulta a higienização e há risco de vazamentos, que podem causar acidentes e contaminação dos alimentos.

\subsubsection{Cores}

$\mathrm{Na}$ UAN do HUB o teto é branco, o que favorece a luminosidade; o piso é bege; as paredes são revestidas de azulejo branco na parte baixa e pintadas na cor creme na parte alta, ao contrário do que se recomenda. De acordo com o índice de reflexão das cores, apenas a cor do teto está adequada. Melhor opção seria a parte alta da parede pintada na cor branca, com maior índice de reflexão para contribuir com a luminosidade, e a parte baixa pintada na cor creme, evitando ofuscamento. A 
cor do piso, apesar do elevado índice de reflexão, é vantajosa em relação à higiene e recomendações sanitárias, por ser clara e permitir melhor identificação das sujidades.

No refeitório apenas o corredor de circulação e lavagem de mãos é revestido de azulejo na cor creme, as demais paredes são pintadas de creme. Tal cor está adequada, pois facilita a iluminação sem causar ofuscamento, porém, seria mais adequado pintar a parte mais alta com uma cor mais clara. O piso é de emborrachado anti-derrapante azul claro, o que é adequado, pois evita acidentes e tem índice de reflexão próximo ao recomendado. Apesar de ser a recomendação, não é interessante que o piso seja de cor escura, com baixo índice de reflexão, pois tornaria o ambiente mais escuro e dificultaria a limpeza.

\subsubsection{Portas}

As portas não são de fechamento automático, são de madeira revestida com material lavável e impermeável, adequadas, portanto, à higienização. Porém, apresentam falhas no revestimento, rachaduras, umidade e descascamento. As portas externas possuem borracha de vedação em sua extremidade inferior, o que impede a passagem de insetos e roedores.

\subsubsection{Janelas}

As janelas da UAN possuem superfície lisa, de fácil higienização, ajustada aos batentes, sem falhas de revestimento e em adequado estado de conservação.

As janelas são localizadas na parte superior das paredes, o que é desejável a fim de se evitar incidência direta de raios solares e garantir a ventilação adequada para evitar o crescimento microbiológico. Todas possuem telas milimétricas para proteção contra insetos.

\subsubsection{Iluminação}

Na UAN, a maior parte da iluminação é natural. Essa iluminação natural, além de ser econômica, exerce efeito bactericida sobre os alimentos e cria um 
ambiente mais agradável para os funcionários. Porém, a iluminação artificial também é importante em caso falta de luz e dias com pouco sol, além do fato da UAN funcionar 24 horas.

A iluminação artificial da área de preparo conta com 26 luminárias, com 4 lâmpadas fluorescentes de $65 \mathrm{~W}$ cada. A luz branca utilizada é a ideal por apresentar, como vantagens, não alterar a cor dos alimentos e não contribuir para 0 aquecimento do ambiente; porém, 11 lâmpadas estão queimadas ou com funcionamento inadequado e falta instalação de 14 lâmpadas, fornecendo 93,4 $\mathrm{W} / 4 \mathrm{~m}^{2}$, valor abaixo do ideal, que é de $150 \mathrm{~W} / 4 \mathrm{~m}^{2}$. Além disso, algumas luminárias estão localizadas atrás das estruturas das coifas, o que dificulta ainda mais a iluminação. Ainda assim, a iluminação é adequada à atividade desenvolvida, sem ofuscamentos, reflexos fortes, sombras e contrastes excessivos.

Observa-se, porém, que as luminárias não possuem proteção e conservação adequadas, o que prejudica a segurança dos funcionários e dos alimentos.

O refeitório tem pouca iluminação natural, pois suas janelas estão na área de circulação e lavagem de mãos e mesmo as paredes sendo incompletas, não são suficientes. Entretanto, para a iluminação artificial são dispostas 14 luminárias com 2 lâmpadas de $65 \mathrm{~W}$ cada, fornecendo $86 \mathrm{~W} / 6 \mathrm{~m}^{2}$, valor adequado e acima do recomendado, que é $50 \mathrm{~W} / 6 \mathrm{~m}^{2}$.

\subsubsection{Ventilação, temperatura e umidade}

Em relação à ventilação e temperatura da unidade, observa-se que os setores são separados por meias-paredes, o que propicia maior circulação do ar e conforto térmico. A presença de coifas e exaustores nas janelas colaboram para estas condições.

A umidade dentro da área de produção é elevada devido ao vapor que sai constantemente dos caldeirões e pela grande freqüência com que é jogada água no piso sem escoamento adequado. A alta umidade propicia a proliferação bacteriana no local.

Foram aferidas temperatura e umidade em algumas áreas da UAN para avaliar adequação (quadro 4). 
Quadro 4: Temperatura e umidade da UAN

\begin{tabular}{|c|c|c|}
\hline & Temperatura & Umidade \\
\hline Cozinha geral & $30,9^{\circ} \mathrm{C}$ & $52 \%$ \\
\hline Cozinha dietética & $30,5^{\circ} \mathrm{C}$ & $53 \%$ \\
\hline Pré-preparo & $30,5^{\circ} \mathrm{C}$ & $52 \%$ \\
\hline Almoxarifado & $28,0^{\circ} \mathrm{C}$ & $54 \%$ \\
\hline Recomendação & $22-26^{\circ} \mathrm{C}$ & $50-60 \%$ \\
\hline
\end{tabular}

Vale ressaltar que a temperatura foi aferida no verão, em horário de pico de produção, quando todos os equipamentos estão em funcionamento. Nos demais horários e em outras épocas do ano, a temperatura seria inferior.

Observa-se que a temperatura foi superior ao recomendado em todos os setores, o que pode causar desconforto para os funcionários e maior risco de proliferação de microorganismos na UAN. Em relação à umidade, todos os valores encontram-se adequados, com umidade entre 50 e 60\%.

A quantidade de janelas observada na área de preparo é suficiente para garantir temperatura e ventilação adequadas e, para melhorar ainda estes fatores, foram instaladas 3 coifas na cozinha geral e 1 coifa na cozinha dietética. Também foram colocados 8 exaustores, porém, não cumprem sua função adequadamente e pouco são ligados, devido ao grande ruído que geram.

O refeitório tem janelas apenas na área de circulação, e estas contribuem pouco para a ventilação. Para melhorar o ambiente foram instalados 4 ventiladores possibilitando temperatura e ventilação mais propícios, porém, é pouco provável que seja alcançado um ambiente ideal e com temperatura agradável, principalmente em dias quentes.

No entanto, o ideal seria que a temperatura fosse agradável sem a necessidade de ventiladores, já que estes podem ser fontes de contaminação dos alimentos por veicularem partículas de sujeira. Ademais, a lavagem dos ventiladores deve ser feita na freqüência adequada para diminuir o risco de contaminação.

\subsubsection{Ruído}

Foi aferido o ruído na UAN por um profissional da engenharia do trabalho com a ajuda de um decibelímetro por 3 dias consecutivos. Durante medição, no horário 
da distribuição das refeições (11:00 horas), o nível de ruído dentro da UAN não ultrapassou os $80 \mathrm{db}$.

Grande parte do barulho na UAN é devido aos equipamentos e choque dos utensílios. Esse nível de ruído poderia ser diminuído, por exemplo, se fossem adquiridos equipamentos e carros silenciosos que se movessem sobre rodízios de borracha.

\subsubsection{Instalações}

As instalações compreendem as redes elétrica, hidráulica e de vapor. As tubulações de água, vapor e elétrica são externas, facilitando a sua manutenção. Entretanto, essas tubulações não são pintadas com cores diferenciadas de acordo com as indicadas pela autoridade competente em segurança e medicina do trabalho, dificultando sua identificação e facilidade nos reparos. A informação sobre a existência interna ou não de revestimento térmico na tubulação de vapor não foi obtida, o que seria importante para conservação da temperatura de vapor. Porém, observou-se que são protegidas por um cano de aço e recobertas por lâminas de alumínio.

Com relação às tomadas, observa-se que estão inadequadas por não serem blindadas, apresentando riscos. Essas tomadas de força não são individualizadas para cada equipamento, sendo, por vezes, necessário desligar um aparelho que estava em uso para utilizar outro cuja necessidade seja maior naquele momento.

As tomadas não são blindadas e, apesar de haver proteção na maioria dos fios, foram observados fios desencapados no balcão de servir.

A UAN possui rede de água filtrada quente e fria, porém as tubulações não são diferenciadas por cores. Em algumas torneiras de água quente pode-se observar a presença de uma proteção de alumínio. As torneiras estão em estado de conservação ruim, sendo que algumas estão quebradas e outras não fecham adequadamente, originando desperdício de água na Unidade, o que faz com que sejam trocadas constantemente. Observou-se que, freqüentemente, falta água em algumas torneiras.

Quanto às tubulações de gás, observou-se que muitas não estão fixadas na parede, sendo facilmente manuseadas, podendo provocar acidentes. 
Foi observado que a UAN possui apenas 1 extintor de incêndio localizado no corredor que liga a área de produção das refeições à entrada da UAN. O extintor está dentro do prazo de validade e em bom estado de conservação. Há uma mangueira de incêndio de 150 m localizada no refeitório.

\subsubsection{Instalações sanitárias e vestiários}

Os banheiros e vestiários dos funcionários estão em localizados fora da área de produção e distribuição de refeições, em local distante, com acesso por passagem coberta e calçada. Eles são independentes para cada sexo, porém não são exclusivos para manipuladores de alimentos. Os mictórios, vasos sanitários e lavatórios estão íntegros e de acordo com a referência da literatura, possuindo 1:15 funcionários. Entretanto, observa-se que, na prática, este número não é suficiente para atender adequadamente aos funcionários, pois se observa que nos horários de entrada e saída dos funcionários, em que a demanda pelo uso dos sanitários e vestiários é maior, há transtorno.

As instalações sanitárias são servidas com água corrente conectadas à rede de esgoto.

Os banheiros e vestiários encontram-se em estado de conservação precário e com muitos aspectos indesejáveis do ponto de vista higiênico-sanitário. Os pisos e as paredes, que são revestidas de cerâmica e azulejos, respectivamente, apresentavam falhas de revestimento, em que há muitos quebrados e com rejunte encardido. O teto apresenta umidade, com muito mofo.

As torneiras são manuais, não possuindo acionamento automático. Há avisos com os procedimentos para lavagem de mãos.

Os vestiários possuem teto baixo e janela de vidro fixa, dificultando a ventilação e favorecendo a elevação da temperatura, o que torna o ambiente abafado. Os armários estão em mau estado de conservação.

\subsubsection{Manejo de resíduos}

No interior da UAN há recipientes para coleta de resíduos de fácil higienização e transporte e devidamente higienizados, com freqüência adequada 
(diária). Os coletores são tampados com acionamento com pedal e revestidos por sacos plásticos descartáveis. O lixo é retirado frequentemente (4 vezes ao dia) da área de processamento, evitando focos de contaminação. Os horários de coleta de lixo são diferentes dos horários de passagem de alimentos para que não haja cruzamentos e, conseqüentemente, contaminação do alimento.

Os resíduos provenientes das clínicas são colocados em sacos plásticos apropriados nas próprias clínicas, são lacrados e ao chegarem à UAN são depositados em coletores específicos, logo na entrada, não cruzando, portanto, a área de produção.

Não há, porém, câmara refrigerada para estocagem dos resíduos, que são retirados da UAN e levados para o setor geral de lixo do hospital, permanecendo em temperatura ambiente até a coleta pública.

\subsubsection{Uniformes}

Os uniformes não são padronizados, porém já foi feito o pedido de novos uniformes. Muitos funcionários utilizam roupas de cor branca, o que facilita a visualização da sujeira. O estado de conservação dos uniformes de alguns funcionários é precário, sendo que alguns se encontram manchados e rasgados. Os sapatos não são padronizados e alguns funcionários homens utilizam botas de borracha branca e antiderrapante. Entre as mulheres, observa-se o uso freqüente de sandálias abertas, saltos altos e solado de material não anti-derrapante.

A maioria dos funcionários utiliza touca, embora alguns utilizem bonés ou gorros. Esta prática é inadequada uma vez que permite que os alimentos sejam contaminados por fios de cabelo.

Luvas de plástico descartáveis são utilizadas para alguns procedimentos, como desfiar frango ou porcionar as refeições nas legumeiras, porém, é freqüente observar funcionários tocando diretamente com as mãos alimentos que já sofreram a etapa final de cocção.

A supervisão do uso de roupas adequadas, bem como de toucas e máscaras, não é realizada diariamente, o que dificulta o controle higiênico-sanitário da Unidade. 


\subsubsection{Equipamentos}

Os equipamentos da UAN estão dispostos de forma a permitir fácil acesso e higienização adequada. Possuem superfícies de contato com os alimentos lisas, impermeáveis, de fácil higienização e de material não contaminante. Alguns, como o forno elétrico, não estão em bom estado de conservação.

Observou-se que a quantidade de fornos é insuficiente. Por falha no planejamento do cardápio, há dias em que tanto a Cozinha Geral, quanto a Cozinha Dietética e a Confeitaria possuem preparações assadas, que demandam o forno no horário do Almoço. Isso gera atrasos na produção, estresse dos funcionários, além de trazer riscos microbiológicos, pois algumas preparações, que não são submetidas à cocção no momento, aguardam armazenadas em locais e temperaturas impróprios.

\subsubsection{Elevadores}

Como a UAN se localiza em andar térreo, não há necessidade de elevadores para recepção e transporte de mercadorias. No entanto, os elevadores são utilizados para os carros-transporte na distribuição das refeições, já que o hospital possui 3 andares superiores ao térreo.

Os elevadores foram construídos e localizados para serem de uso exclusivo da UAN. Mas, na prática, isso não acontece, o que acaba sendo uma fonte de contaminação para as refeições prontas. Eles são feitos de material apropriado, porém, encontram-se em mau estado de conservação; e não há manutenção preventiva, apenas curativa, o que prejudica o bom funcionamento.

\subsubsection{Móveis e Utensílios}

As mesas e bancadas da UAN são todas de material apropriado (aço inox), sendo resistentes, impermeáveis, com superfícies íntegras, em bom estado de conservação e em número suficiente para atender à demanda da unidade. 


\subsubsection{Dimensionamento da estrutura física}

As medidas da estrutura física da UAN foram aferidas a partir da planta obtida junto ao departamento de engenharia do HUB, com um dos arquitetos responsáveis. A tabela 4 mostra o comprimento, a largura e as áreas de cada setor da UAN dividida, de acordo com Mezomo (2004), em: recepção e estocagem de mercadorias; distribuição; e demais áreas. A área total foi obtida pela soma de todas as áreas, pois dessa forma as paredes internas da UAN são desconsideradas. As adequações das áreas foram calculadas de acordo com a porcentagem recomendada, levando-se em consideração que a área total representa 100\%.

Em comparação à literatura, a área total da UAN do HUB apresenta-se com superávit, sendo que, segundo Mezomo (2004), a área da UAN deve ser de $2 \mathrm{~m}^{2}$ por leito do hospital para UAN com distribuição de refeições centralizada e o total calculado nesta unidade é de 2,48 $\mathrm{m}^{2} /$ leito. Este valor estabelecido por Mezomo (2004) é para a unidade de um hospital com 200 leitos e o HUB possui 289 leitos. Isso faz com que essa referência não possa ser utilizada com precisão para o HUB. Outro ponto a ser considerado é que a UAN do HUB fornece refeições para vários acompanhantes de pacientes, funcionários do hospital, alunos, estagiários, residentes, os quais não estão incluídos nos cálculos de Mezomo (2004) e que fazem grande diferença no número de refeições produzidas e, conseqüentemente, no dimensionamento da UAN. 
Tabela 4: Distribuição das áreas da UAN por setores

\begin{tabular}{|c|c|c|c|c|}
\hline \multicolumn{2}{|l|}{ Setor } & $\begin{array}{l}\text { Comprimento } \\
\text { (m) }\end{array}$ & $\begin{array}{l}\text { Largura } \\
\text { (m) }\end{array}$ & $\begin{array}{l}\text { Área } \\
\left(\mathrm{m}^{2}\right)\end{array}$ \\
\hline & Área de distribuição de refeições & 14,8 & 9,4 & 139,12 \\
\hline & Refeitório & 13,1 & 10,6 & 138,86 \\
\hline & Circulação no refeitório & 6,6 & 4,2 & 27,72 \\
\hline & Área de higienização de utensílios de clínica & 2,8 & 2,6 & 7,28 \\
\hline Distribuição & Área de higienização de utensílios do refeitório & 3,7 & 3,6 & 13,32 \\
\hline & Área de recepção de pratos do refeitório & 3,6 & 2,2 & 7,92 \\
\hline & Área de distribuição do café & 3,4 & 2,3 & 7,82 \\
\hline & Área de higienização de panelas & 6,6 & 2,0 & 13,2 \\
\hline & Armazenamento de utensílios & 5,4 & 0,8 & 4,32 \\
\hline \multicolumn{2}{|l|}{ Total } & & & 359,56 \\
\hline \multirow{6}{*}{$\begin{array}{c}\text { Recepção e } \\
\text { estocagem de } \\
\text { mercadorias }\end{array}$} & Almoxarifado central & 11,3 & 6,0 & 67,8 \\
\hline & Corredor de recepção & 7,2 & 1,6 & 11,52 \\
\hline & Dispensa dia & 6,3 & 4,6 & 28,98 \\
\hline & Material de limpeza & 3 & 1 & 3 \\
\hline & Câmaras de refrigeração & 5,2 & 3 & 15,6 \\
\hline & Câmara de carnes & 2,8 & 1,8 & 5,04 \\
\hline \multicolumn{2}{|l|}{ Total } & & & 131,94 \\
\hline \multirow{13}{*}{ Demais áreas } & Açougue & 4,5 & 2,4 & 10,8 \\
\hline & Pré-preparo da cozinha geral & 5,0 & 4,2 & 21 \\
\hline & Ilha de cocção & 8,2 & 6,0 & 49,2 \\
\hline & Confeitaria & 3,6 & 3,4 & 12,24 \\
\hline & Colação & 3,6 & 2,7 & 9,72 \\
\hline & Cozinha dietética & 4,5 & 4 & 18 \\
\hline & Área de fornos & 3,6 & 3,2 & 11,52 \\
\hline & Área de higienização de panelas & 7,5 & 2,8 & 21 \\
\hline & Área do lixo & 3,4 & 1,1 & 3,74 \\
\hline & Sala dos nutricionistas & 6,4 & 3,4 & 21,76 \\
\hline & Banheiro dos nutricionistas e técnicas & 3 & 1 & 3 \\
\hline & Circulação para a produção & 10,2 & 1,4 & 14,28 \\
\hline & Recepção e sala da nutricionista chefe & 6,2 & 4,4 & 27,28 \\
\hline \multicolumn{4}{|l|}{ Total } & 223,54 \\
\hline \multicolumn{4}{|l|}{ ÁREA TOTAL } & 715,04 \\
\hline
\end{tabular}


Os setores analisados, segundo Mezomo, são: recepção e estocagem de mercadorias; distribuição; e demais áreas. A área da recepção e estocagem (Almoxarifado central, Corredor de recepção, Dispensa dia, Material de limpeza, Câmaras de refrigeração, Câmaras de congelamento), segundo Mezomo, deve representar 20\% da área total. Essa área é 132, $95 \mathrm{~m}^{2}$, ou seja, 18,5 \% da área total da UAN, desse setor está subdimensionado.

A área de distribuição (Área de distribuição de refeições, Refeitório, Circulação no refeitório, Área de higienização de legumeiras, Área de higienização de utensílios do refeitório, Área de recepção de pratos do refeitório, Área de distribuição do café, Circulação na área de higienização e Armazenamento de utensílios) deve representar, segundo Mezomo, 45\% da área total da UAN. Esse setor possui $359 \mathrm{~m}^{2}$, se $45 \%$ da área total correspondem a $321.3 \mathrm{~m}^{2}$ o setor de distribuição está superestimado em 11,8\%.

As demais dependências devem corresponder aos 35\% restantes da área total. Esse setor no caso da UAN do HUB composto pelo açougue, área de Prépreparo da cozinha geral, Ilha de cocção, Confeitaria, Colação, Cozinha dietética, Área de fornos, Área de higienização de panelas, Área do lixo, Sala dos nutricionistas, Banheiro dos nutricionistas e técnicas, Circulação para a produção, Recepção e sala do nutricionista chefe, corresponde a $223,5 \mathrm{~m}^{2}$, que é menor que o preconizado de $250 \mathrm{~m}^{2}$ (35\% de 715), ou seja, está subdimensionada em 11\%.

Desse modo, pode-se inferir que a UAN do HUB está adequada, segundo Mezomo em relação à área total, porém essa adequação é questionável, pois apesar da UAN do HUB ser uma unidade hospitalar, possui uma clientela essencialmente composta por funcionários, residentes, internos e estagiários. São servidas, em média, diariamente, 350 refeições apenas no almoço. Assim, o maior público não consiste nos pacientes e sim nos funcionários que fazem as refeições na UAN do hospital.

Por isso, faz-se necessária uma análise segundo o número de refeições servidas. Silva Filho (1986) estimou a área da UAN baseando-se no número de refeições servidas pela UAN em uma única etapa e um coeficiente pré-estabelecido. Desse modo, a área total da UAN do HUB deveria ser de $210 \mathrm{~m}^{2}$ (700 refeições $\mathrm{x}$ 0,3). Ou seja, a área total da UAN do HUB está superestimada também de acordo com esse padrão. 


\subsection{SETORES DA UAN}

Cada área da UAN foi descrita e comparada com os parâmetros de referência. A fim de facilitar a compreensão, a planta baixa da UAN foi colocada em anexo (Anexo 2).

\subsection{1 Área de aprovisionamento}

A área de recepção de mercadorias é externa à UAN, e como se situa no térreo, é de fácil acesso aos fornecedores para descarga de gêneros alimentícios. No entanto, não existe local apropriado para o recebimento de mercadorias, que são recebidas na porta do almoxarifado. Há uma plataforma de recebimento, sem proteção lateral e coberta com um pequeno toldo. No momento da entrega, as mercadorias ficam expostas ao tempo. A plataforma de entrada de gêneros situa-se em frente à rua onde há tráfego de carros e pessoas, o que pode constituir-se em pontos de contaminação.

A área de inspeção é aparelhada com balança tipo plataforma para pesagem de mercadorias. Não há área de pré-lavagem, sendo os alimentos diretamente acondicionados em caixas ou sacos plásticos próprios da UAN e transportados para as câmaras frigoríficas. Apesar disso, há pré-lavagem de forma improvisada para as embalagens de leite, antes de seu armazenamento.

\subsubsection{Almoxarifado}

O almoxarifado possui porta de entrada única, com dimensões apropriadas, com borracha de vedação na parte inferior. O piso é de material lavável e resistente e não possui ralos de forma a evitar a entrada de pragas na área de armazenamento dos alimentos. No entanto, há excesso de rejunte que acumula umidade e o piso está em mau estado de conservação.

A iluminação é adequada para permitir inspeção e leitura dos rótulos dos alimentos. Há janelas teladas, que propiciam boa ventilação e claridade sem incidência direta de raios solares sobre as mercadorias. Há, também, iluminação artificial, com lâmpadas fluorescentes. 
A distribuição das prateleiras encontra-se dentro das normas: afastadas das paredes, têm altura suficiente para permitir higienização do piso, são de aço, revestidas de tinta lavável e com pés de borracha.

Os estrados são de madeira, pintados com tinta lavável, fenestrados e os pés não são protegidos com canoplas. A capacidade de armazenamento atende às necessidades da UAN. Há uma escada de ferro sem patamar e rodízios. Não há extintor de incêndio nem protetor contra ratos no rodapé.

Todos os gêneros são retirados da caixa do fornecedor e acondicionados em caixas plásticas vazadas da própria UAN, previamente higienizadas. No entanto, observa-se a presença, ainda, de algumas caixas de papelão, que impedem a circulação de ar entre os gêneros e permitem a proliferação de pragas.

\subsubsection{Câmaras Frigoríficas}

Há 4 câmaras frias, cada uma armazenando exclusivamente os gêneros: 1 de carnes; 2 para hortifruti e 1 para laticínios e sobremesas. Há refrigeradores industriais e freezers para armazenamento de polpas de frutas e sucos envasados. Não há, no entanto, local específico para guarda de alimentos prontos. A temperatura das câmaras é monitorada por termômetro tipo mostrador localizado na parte externa. No entanto, elas não apresentam ante-câmara e são abertas com muita freqüência, o que dificulta a manutenção da temperatura.

As prateleiras, paredes e teto das câmaras são compostas de material adequado, resistente e lavável, facilitando a higienização. O piso é monolítico, resistente e lavável, é poroso, o que aumenta a umidade no local e facilita o desenvolvimento de microorganismos. O desnível existente entre o piso das câmaras e da unidade facilita o escoamento da água no momento da lavagem. Não há presença de ralos internos de forma a evitar a entrada de insetos.

As portas são herméticas, revestidas em aço inox, mas não há dispositivo de segurança para permitir abertura por dentro.

\subsection{4 Área de Pré-preparo}

Existem áreas delimitadas para o pré-preparo de vegetais, cereais, frutas e carnes. São próximas e se localizam em frente à área de cocção geral. São 
separadas por meias-paredes, o que é adequado para assegurar melhor iluminação e ventilação.

Não possuem pias exclusivas para lavagem de mãos. Todos os funcionários, ao entrar na UAN, dispõem de um lavatório com cinco torneiras, dotadas de saboneteiras com sabonete líquido, álcool para desinfecção das mãos, papel toalha e lixeira acionada por pedal, onde são higienizadas as mãos antes do início do trabalho e após cada interrupção.

Todas as bancadas são de alvenaria cobertas de inox, material apropriado por ser resistente, liso, impermeável e de fácil limpeza e possuem cubas de volume adequado para a realização das atividades. No entanto, como as bancadas são insuficientes, torna-se necessário o uso de bancadas e mesas auxiliares, que são todas de inox.

As paredes são íntegras, no entanto faltam azulejos e a tubulação hidráulica apresenta vazamentos.

Há ainda tábuas de altileno e local para dispor todos os equipamentos utilizados nas operações. As tábuas são devidamente higienizadas após a utilização. O açougue tem como incovenientes, além do fato de situar-se em frente à área de cocção, sem barreira física, ausência de climatização e localização muito afastada das câmaras frigoríficas.

\subsection{5 Área de preparo}

A área de preparo compreende a Cozinha Geral (preparo da dieta geral, que atende à grande maioria dos clientes, incluindo os funcionários, os pacientes sem necessidades nutricionais diferenciadas e seus acompanhantes), Cozinha Dietética (confecção das dietas especiais, oferecidas aos pacientes que requerem alterações na composição ou consistência da dieta normal), a Confeitaria (preparo de pães e bolos) e Área de Colação (preparo de frutas, sucos e vitaminas).

A Cozinha Geral é uma ilha de cocção localizada no centro da UAN, em frente aos setores de pré-preparo, sem barreira física. É via de circulação de pessoas da produção, tornando-se local de risco de acidentes e possível contaminação física de alimentos que estão em fase de cocção. O dimensionamento da área é suficiente para atender à demanda da UAN. 
A Cozinha Dietética está situada em área específica, separada dos outros setores da UAN. O acesso é restrito aos funcionários do setor.

A confeitaria ocupa uma área separada por meias paredes. A batedeira possui local fixo, que facilita a utilização. Os demais equipamentos necessários, como liquidificador, geladeira e fornos, devido à limitação da área, se situam em outros setores da UAN, o que acarreta constantes deslocamentos dos equipamentos ou dos funcionários da confeitaria.

A colação tem área suficiente para o fim a que se destina. É separada da confeitaria por meia parede e tem os equipamentos necessários para a realização das atividades.

Nenhuma área de preparo é dotada de uma pia exclusiva para higienização das mãos dos manipuladores, nem nas proximidades mais imediatas.

\subsection{6 Área de distribuição}

A distribuição das refeições é feita em local próximo à área de cocção, com o auxílio de bancadas de inox e balcões térmicos.

$\mathrm{Na}$ cozinha dietética, os alimentos das cubas do balcão térmico são distribuídos em legumeiras pelas funcionárias do setor, na modalidade empratado. As bandejas são arrumadas em carros transporte e levadas às clínicas.

Os alimentos provenientes da cozinha geral para pacientes e acompanhantes são acondicionados em cubas e porcionados pelos funcionários, com modalidade empratado. Já os alimentos do refeitório dos funcionários são colocados em balcão térmico próprio para serem servidos pelos próprios clientes, na modalidade cafeteria.

A área de distribuição é suficiente para permitir um processo rápido de porcionamento, levando cerca de 30 minutos. O porcionamento deve ser realizado no menor tempo possível e com as mais rigorosas condições de higiene, já que é um ponto crítico no controle da qualidade higiênico-sanitária dos alimentos.

O refeitório tem área suficiente para atender à clientela. Por estar localizado adjacente à área de produção, distribuição, lavagem e corredor de passagem de carros-transporte, o ruído é intenso, prejudicando a qualidade do ambiente. 


\subsection{7 Área para higienização}

A área para higienização dos utensílios utilizados no processamento é delimitada por parede completa, porém sem prejuízo de iluminação e ventilação. Conta com um sistema de drenagem bem dimensionado, local para dispor os utensílios que aguardam a higienização, cubas profundas, porém não conta com local para guarda do material após a higienização, que ficam expostos.

No entanto, as instalações hidráulicas estão em estado precário de conservação. Não há máquina para lavagem de louças, sendo a lavagem manual.

A área para higienização dos utensílios utilizados para distribuição das refeições nas clínicas conta com uma área específica, adjacente ao local de chegada dos carros-transporte, obedecendo a um fluxo racional de operação. Toda a instalação hidráulica encontra-se em bom estado de conservação.

A área para higienização dos utensílios do refeitório é adjacente ao restaurante, comunicando-se com este por um de guichê para recepção do material usado. Há instalação para guarda do material após a higienização.

\subsection{CLASSIFICAÇÃO DO ESTABELECIMENTO}

A UAN analisada atendeu a 59\% dos itens do check-list para estrutura física, excluindo-se os itens que não se aplicam ao estabelecimento. Assim, a UAN entra no grupo 2 (51\% a $75 \%$ de atendimento dos itens).

Um estudo de metanálise realizado em 50 estabelecimentos produtores de alimentos no Distrito Federal, avaliou o cumprimento dos itens do check-list, e revelou que a maioria das Unidades de Alimentação e Nutrição (66,7\%) se enquadram no grupo 3, diferentemente da UAN analisada (AKUTSU, 2005).

\subsection{COMPARAÇÃO DA ESTRUTURA DA UAN ATUAL EM RELAÇÃO À AVALIAÇÃO ANTERIOR}

Algumas melhorias foram observadas na UAN nos últimos 3 anos. Isso pôde ser constatado por meio de comparação com o check-list anterior (PIMENTEL E GOMES, 2003). 
A área externa hoje é ausente de matos e materiais em desuso e esgoto a céu aberto e, devido à higienização mais rigorosa, diminuíram muito os focos de insetos e roedores. Já está sendo implementada POP para higienização, inclusive de área externa. O depósito de lixo geral do hospital, que se situava na lateral externa da UAN, foi afastado para uma distância de aproximadamente $300 \mathrm{~m}$.

A rede de esgoto de todas as enfermarias de uma parte do hospital atravessava toda a extensão da UAN. Essa rede foi desviada para outro local.

Em relação à iluminação, aumentou-se 0 número de lâmpadas, principalmente na área de açougue, substituição de soquetes e reatores, o que melhorou a luminosidade e, conseqüentemente, melhor qualidade de serviço e menor risco de acidentes de trabalho. Porém, continua sem calhas de proteção, pois não há mais o modelo disponível no mercado.

Nas paredes, foram substituídos os azulejos quebrados e cantoneiras foram colocadas nas quinas.

No tocante à proteção contra insetos e roedores, muitas melhorias foram constatadas: todos os exaustores hoje contém filtros de ar e telas milimétricas, presentes também em todas as janelas; nas portas externas foram colocadas borrachas de vedação e telas para proteção.

A área de higienização de utensílios foi toda reformada para seguir fluxo racional de operações, evitando cruzamentos. Além disso, hoje conta com piso antiderrapante e novas cubas, prateleiras e bancadas de inox.

Os armários de madeira para guarda de material foram todos substituídos por armários de alvenaria revestidos com azulejo. Além disso, em todas as áreas da UAN, as mesas e bancadas de madeira foram substituídas por inox. 


\subsection{PROPOSTAS PARA MELHORAR A ESTRUTURA FÍSICA}

A partir da análise da estrutura física da UAN, foi observado que muitos aspectos poderiam ser melhorados para garantir a qualidade higiênico-sanitária dos alimentos. O ideal seria a construção de uma nova UAN, com base nas exigências das legislações atuais; e existe área disponível para isso. No entanto, enquanto isso não é possível, é necessário que a área atual sofra mudanças em curto prazo para continuar a funcionar com qualidade, a citar:

- Reforma geral de revestimento, piso, teto e parede;

- Conserto geral do sistema hidráulico (tubulações de esgoto, substituição de registros, torneiras, sifões;

- Diferenciação das tubulações de água, esgoto, vapor, energia elétrica e gás por cores;

- Manutenção preventiva dos equipamentos e elevadores, para evitar consertos de urgência e transtornos;

- Substituição do gramado existente na área de recepção de gêneros por calçadas;

- Instituição do setor de pré-lavagem de frutas e hortaliças;

- Proteção para lâmpadas, principalmente na área de cocção;

- Construção de instalações sanitárias adequadas e exclusivas para manipuladores de alimentos, de fácil acesso;

- Pias exclusivas para lavagem de mãos na área de manipulação de alimentos;

- Modificação do sistema de escoamento, com a inclusão de ralos sifonados e grelhas apropriadas;

- Reforma do sistema de exaustão para aumentar a capacidade de sucção de gases;

- Aquisição de carros-transporte silenciosos que se movam sobre rodízios de borracha e sistema de exaustão mais silencioso, para reduzir o ruído no interior na UAN. 


\section{CONSIDERAÇÃOES FINAIS}

Pessoas enfermas, algumas bastante debilitadas em conseqüência da doença de base, necessitam de todas as medidas que visem a sua recuperação ao menor tempo possível de internação. Por isso é importante todas as medidas que visem a garantia da inocuidade das refeições servidas, rastreando e controlando todas as possibilidades de contaminação química, física e microbiológica que poderiam agravar a saúde dos pacientes. Para isso, um dos fatores essenciais a se considerar é uma área física que atenda aos requisitos estabelecidos nas legislações sanitárias.

A área física analisada não é ideal em muitos aspectos (como localização, leiaute, fluxograma e composição de setores). O ideal seria a construção de uma nova UAN, que atendesse aos requisitos. Mas enquanto isso não ocorre, é importante que haja correção das principais falhas identificadas, além de aplicação de Boas Práticas de Fabricação, visando garantia da qualidade dos alimentos. 


\section{REFERÊNCIAS}

ABERC - Associação brasileira das empresas de refeição coletiva. Manual ABERC de Práticas de Elaboração e Serviço de Refeições para Coletividades. $2^{\mathrm{a}}$ edição, 1995.

AKUTSU, R. C. Valores Organizacionais e Atenção Dietética: estudo de caso em empresas petroquímicas. 2001. 126 f. Dissertação. (Mestrado em Nutrição) Escola de Nutrição - Universidade Federal da Bahia. Salvador, 2001

AKUTSU, R.C. et al. Adequação das boas práticas de fabricação em serviços de alimentação. Rev Nutrição Campinas 18(3): 419-427, 2005.

BRASIL, 2001. Ministério do Trabalho e Emprego. Fundação Jorge Duprat Figueiredo de Segurança e Medicina Do Trabalho. Ponto de verificação ergonômica: soluções práticas e de fácil aplicação para melhorar a segurança, a saúde e as condições de trabalho. p. 169, 182, 208, 221.

BRASIL, 1994. Ministério do Trabalho. Norma regulamentadora $n^{\circ}$ 17. Brasília, p. $9-13,36$.

CHESCA, A.C.; MOREIRA, P. A.; ANDRADE, S.C.J. de; Equipamentos e Utensílios de Unidades de Alimentação e Nutrição: um risco constante de contaminação das refeições. Higiene Alimentar 17 (114/115): 20- 23, 2003.

CONSEA. Documento de Referência da II Conferência Nacional de Segurança Alimentar e Nutricional. Brasília: CONSEA, 2004.

CONSELHO FEDERAL DE NUTRICIONISTAS. Resolução n. 380, de 28 de dezembro de 2005. Dispõe sobre a definição das áreas de atuação do nutricionista e suas atribuições, estabelece parâmetros numéricos de referência, por área de atuação, e dá outras providências.

MEZOMO, Iracema. Os Serviços de Alimentação: Planejamento e Administração. Editora Terra, 5a edição. São Paulo, 2004.

OLIVEIRA, Margarida Pacheco. Avaliação da área física e fluxo de operações da cozinha do Hospital Regional de Brazlândia. Monografia (especialização em Qualidade de Alimentos) - Universidade de Brasília. Centro de Excelência em Turismo. Brasília, 2003.

PASSOS, L. D. M. Organização de Cozinhas Hospitalares. Associação Paulista de Hospitais, $3^{a}$ edição. São Paulo, 1982.

PIMENTEL, Raimunda \& GOMES, Renata. Avaliação da área Física da UAN do Hospital Universitário da Universidade de Brasília. Trabalho apresentado para conclusão da disciplina de Vigilância Sanitária da Pós-graduação em Nutrição Humana. Brasília, 2003. 
SEBRAE;SENAI. Guia para implantação de boas práticas de fabricação (BPF) e do sistema APPCC. Rio de Janeiro, 2000 apud OLIVEIRA, Margarida Pacheco. Avaliação da área física e fluxo de operações da cozinha do Hospital Regional de Brazlândia. Monografia (especialização em Qualidade de Alimentos) Universidade de Brasília. Centro de Excelência em Turismo. Brasília, 2003.

SILVA FILHO, Antônio Romão. Manual Básico para Planejamento e Projetos de Restaurantes e Cozinhas Industriais. Ed. Varela. São Paulo, 1996.

SILVA JR, Eneo Alves. Manual de controle Higiênico-Sanitário em Alimentos. Ed Varela. São Paulo, 1995.

TEIXEIRA, Suzana; MILET, Z.; CARVALHO, J.; BISCONTINI, T.M. Administração aplicada às unidades de alimentação e nutrição. Atheneu. São Paulo, 2004.

TODHUNTER, E. N. Some aspects of the history of dietetics. Word Review of Nutrition and Dietetics, Basel, Switzzeland, S. Karger, v. 5, p. 32 -78, 1965.

TRIGO, Viviano C. Manual Prático de higiene e sanidade nas unidades de alimentação e nutrição. São Paulo: Varela, 1999.

Estatísticas do HUB. Disponível em http://www.hub.unb.br/Institucional/estatist.htm. Acessado em 10/12/05.

VASCONCELOS, F. A. G. O Nutricionista no Brasil: uma análise histórica. Revista de Nutrição, Campinas, v. 15, n² 2, p.127-138, ago. 2002. 


\section{ANEXOS}

ANEXO 1: check-list: lista de verificação das boas práticas de fabricação em estabelecimentos produtores/ industrializadores de alimentos

\begin{tabular}{|c|c|c|c|}
\hline \multirow{2}{*}{\multicolumn{4}{|c|}{$\begin{array}{l}\text { B - AVALIAÇÃO } \\
\text { 1. EDIFICAÇÃO E INSTALAÇÕES }\end{array}$}} \\
\hline & & & \\
\hline \multicolumn{4}{|l|}{ 1.1 ÁREA EXTERNA: } \\
\hline \begin{tabular}{|l|} 
1.1.1 Área externa livre de focos de insalubridade, de objetos \\
em desuso ou estranhos ao ambiente, de vetores e outros \\
animais no pátio e vizinhança; de focos de poeira; de \\
acúmulo de lixo nas imediações, de água estagnada, dentre \\
outros.
\end{tabular} & & $\mathrm{X}$ & \\
\hline \begin{tabular}{|l|}
1.1 .2 Vias de acesso interno com superfície dura ou \\
pavimentada, adequada ao trânsito sobre rodas, escoamento \\
adequado e limpas
\end{tabular} & $\mathrm{X}$ & & \\
\hline \multicolumn{4}{|l|}{ 1.2 ACESSO: } \\
\hline 1.2.1 Direto, não comum a outros usos ( habitação). & & $\mathrm{X}$ & \\
\hline \multicolumn{4}{|l|}{ 1.3 ÁREA INTERNA: } \\
\hline $\begin{array}{l}\text { 1.3.1 Área interna livre de objetos em desuso ou estranhos } \\
\text { ao ambiente. }\end{array}$ & $\mathrm{X}$ & & \\
\hline \multicolumn{4}{|l|}{ 1.4 PISO: } \\
\hline $\begin{array}{l}\text { 1.4.1 Material que permite fácil e apropriada higienização } \\
\text { (liso, resistente, drenados com declive, impermeável e } \\
\text { outros). }\end{array}$ & $\mathrm{x}$ & & \\
\hline $\begin{array}{l}\text { 1.4.2 Em adequado estado de conservação (livre de defeitos, } \\
\text { rachaduras, trincas, buracos e outros). }\end{array}$ & & $\mathrm{X}$ & \\
\hline \begin{tabular}{|l} 
1.4.3 Sistema de drenagem dimensionado adequadamente, \\
sem acúmulo de resíduos. Drenos, ralos sifonados e grelhas \\
colocados em locais adequados de forma a facilitar o \\
escoamento e proteger contra a entrada de baratas, roedores \\
etc.
\end{tabular} & & $\mathrm{X}$ & \\
\hline
\end{tabular}

\begin{tabular}{|c|c|c|c|}
\hline \multirow{2}{*}{\multicolumn{4}{|c|}{$\frac{\text { B - AVALIAÇÃO }}{1 \text { 15 TFTOS. }}$}} \\
\hline & & & \\
\hline $\begin{array}{l}\text { 1.5.1 Acabamento liso, em cor clara, impermeável, de fácil } \\
\text { limpeza e, quando for o caso, desinfecção. }\end{array}$ & & $\mathrm{X}$ & \\
\hline $\begin{array}{l}\text { 1.5.2 Em adequado estado de conservação (livre de trincas, } \\
\text { rachaduras, umidade, bolor, descascamentos e outros). }\end{array}$ & & $\mathrm{X}$ & \\
\hline \multicolumn{4}{|l|}{ 1.6 PAREDES E DIVISÓRIAS: } \\
\hline $\begin{array}{l}\text { 1.6.1 Acabamento liso, impermeável e de fácil higienização } \\
\text { até uma altura adequada para todas as operações. De cor } \\
\text { clara. }\end{array}$ & $\mathrm{x}$ & & \\
\hline
\end{tabular}









\begin{tabular}{|c|c|c|c|}
\hline satisfatório estado de conservação. & & & \\
\hline 1.10.8 lluminação e ventilação adequadas. & & $\mathrm{X}$ & \\
\hline $\begin{array}{l}\text { 1.10.9 Instalações sanitárias dotadas de produtos destinados } \\
\text { à higiene pessoal: papel higiênico, sabonete líquido inodoro } \\
\text { anti-séptico ou sabonete líquido inodoro e anti-séptico, } \\
\text { toalhas de papel não reciclado para as mãos ou outro } \\
\text { sistema higiênico e seguro para secagem. }\end{array}$ & & $x$ & \\
\hline $\begin{array}{l}\text { 1.10.10 Presença de lixeiras com tampas e com } \\
\text { acionamento não manual. }\end{array}$ & & $x$ & \\
\hline 1.10.11 Coleta freqüente do lixo. & $\mathrm{X}$ & & \\
\hline $\begin{array}{l}\text { 1.10.12 Presença de avisos com os procedimentos para } \\
\text { lavagem das mãos. }\end{array}$ & $\mathrm{X}$ & & \\
\hline $\begin{array}{l}\text { 1.10.13 Vestiários com área compatível e armários } \\
\text { individuais para todos os manipuladores. }\end{array}$ & $\mathrm{X}$ & & \\
\hline $\begin{array}{l}\text { 1.10.14 Duchas ou chuveiros em número suficiente } \\
\text { (conforme legislação específica), com água fria ou com água } \\
\text { quente e fria. }\end{array}$ & & $\mathrm{x}$ & \\
\hline $\begin{array}{l}\text { 1.10.15 Apresentam-se organizados e em adequado estado } \\
\text { de conservação. }\end{array}$ & & $\mathrm{x}$ & \\
\hline \multicolumn{4}{|l|}{ 1.11 INSTALAÇÕES SANITÁRIAS PARA VISITANTES E OUTROS: } \\
\hline $\begin{array}{l}\text { 1.11.1 Instaladas totalmente independentes da área de } \\
\text { produção e higienizados. }\end{array}$ & & & $\mathrm{X}$ \\
\hline \multicolumn{4}{|l|}{ 1.12 LAVATÓRIOS NA ÁREA DE PRODUÇÃO: } \\
\hline $\begin{array}{l}\text { 1.12.1 Existência de lavatórios na área de manipulação com } \\
\text { água corrente, dotados preferencialmente de torneira com } \\
\text { acionamento automático, em posições adequadas em } \\
\text { relação ao fluxo de produção e serviço, e em número } \\
\text { suficiente de modo a atender toda a área de produção }\end{array}$ & & $\mathrm{X}$ & \\
\hline $\begin{array}{l}\text { 1.12.2 Lavatórios em condições de higiene, dotados de } \\
\text { sabonete líquido inodoro anti-séptico ou sabonete líquido } \\
\text { inodoro e anti-séptico, toalhas de papel não reciclado ou } \\
\text { outro sistema higiênico e seguro de secagem e coletor de } \\
\text { papel acionados sem contato manual. }\end{array}$ & & $\mathrm{X}$ & \\
\hline
\end{tabular}

\begin{tabular}{|c|c|c|c|}
\hline B - AVALIAÇÃO & SIM & NÃO & $\mathrm{NA}\left({ }^{*}\right)$ \\
\hline \multicolumn{4}{|l|}{ 1.13 ILUMINAÇÃO E INSTALAÇÃO ELÉTRICA: } \\
\hline $\begin{array}{l}\text { 1.13.1 Natural ou artificial adequada à atividade } \\
\text { desenvolvida, sem ofuscamento, reflexos fortes, sombras e } \\
\text { contrastes excessivos. }\end{array}$ & $\mathrm{x}$ & & \\
\hline $\begin{array}{l}\text { 1.13.2 Luminárias com proteção adequada contra quebras } \\
\text { e em adequado estado de conservação. }\end{array}$ & & $\mathrm{x}$ & \\
\hline 1.13.3 Instalações elétricas embutidas ou quando exteriores & $\mathrm{X}$ & & \\
\hline
\end{tabular}


revestidas por tubulações isolantes e presas a paredes e tetos.

\subsection{VENTILAÇÃO E CLIMATIZAÇÃO:}

1.14.1 Ventilação e circulação de ar capazes de garantir o conforto térmico e o ambiente livre de fungos, gases, fumaça, pós, partículas em suspensão e condensação de vapores sem causar danos à produção.

1.14.2 Ventilação artificial por meio de equipamento(s) higienizado(s) e com manutenção adequada ao tipo de equipamento.

1.14.3 Ambientes climatizados artificialmente com filtros adequados.

1.14.4 Existência de registro periódico dos procedimentos de limpeza e manutenção dos componentes do sistema de climatização (conforme legislação específica) afixado em local visível.

1.14.5 Sistema de exaustão e ou insuflamento com troca de ar capaz de prevenir contaminações.

1.14.6 Sistema de exaustão e ou insuflamento dotados de filtros adequados.

1.14.7 Captação e direção da corrente de ar não seguem a direção da área contaminada para área limpa.

1.15 HIGIENIZAÇÃO DAS INSTALAÇÕES:

1.15.1 Existência de um responsável pela operação de higienização comprovadamente capacitado.

1.15.2 Freqüência de higienização das instalações adequada.

1.15.3 Existência de registro da higienização.

1.15.4 Produtos de higienização regularizados pelo Ministério da Saúde.

1.15.5 Disponibilidade dos produtos de higienização necessários à realização da operação.

1.15.6 A diluição dos produtos de higienização, tempo de contato e modo de uso/aplicação obedecem às instruções recomendadas pelo fabricante.

1.15.7 Produtos de higienização identificados e guardados em local adequado.

1.15.8 Disponibilidade e adequação dos utensílios (escovas, esponjas etc.) necessários à realização da operação. Em bom estado de conservação.

1.15.9 Higienização adequada. \begin{tabular}{|l||l|l|}
\hline & & \\
\hline
\end{tabular} (n)

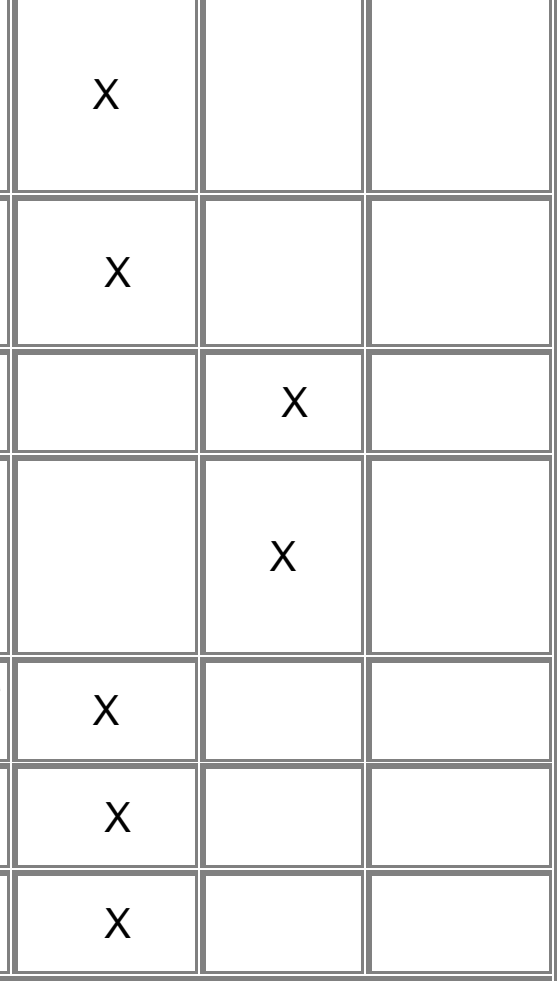
1.16 CONTROLE INTEGRADO DE VETORES E PRAGAS URBANAS: 


\begin{tabular}{|c|c|c|c|}
\hline vidência de sua presença como fezes, ninhos e outros. & & & \\
\hline $\begin{array}{l}\text { 1.16.2 Adoção de medidas preventivas e corretivas com o } \\
\text { objetivo de impedir a atração, o abrigo, o acesso e ou } \\
\text { proliferação de vetores e pragas urbanas. }\end{array}$ & $\mathrm{x}$ & & \\
\hline $\begin{array}{l}\text { 1.16.3 Em caso de adoção de controle químico, existência } \\
\text { de comprovante de execução do serviço expedido por } \\
\text { empresa especializada. }\end{array}$ & $\mathrm{x}$ & & \\
\hline 1.17 ABASTECIMENTO DE ÁGUA: & & & \\
\hline 1.17.1 Sistema de abastecimento ligado à rede pública. & $\mathrm{X}$ & & \\
\hline $\begin{array}{l}\text { 1.17.2 Sistema de captação própria, protegido, revestido e } \\
\text { distante de fonte de contaminação. }\end{array}$ & $\mathrm{x}$ & & \\
\hline $\begin{array}{l}\text { 1.17.3 Reservatório de água acessível com instalação } \\
\text { hidráulica com volume, pressão e temperatura adequados, } \\
\text { dotado de tampas, em satisfatória condição de uso, livre de } \\
\text { vazamentos, infiltrações e descascamentos. }\end{array}$ & $\mathrm{X}$ & & \\
\hline $\begin{array}{l}\text { 1.17.4 Existência de responsável comprovadamente } \\
\text { capacitado para a higienização do reservatório da água. }\end{array}$ & $\mathrm{x}$ & & \\
\hline $\begin{array}{l}\text { 1.17.5 Apropriada freqüência de higienização do } \\
\text { reservatório de água. }\end{array}$ & $\mathrm{x}$ & & \\
\hline $\begin{array}{l}\text { 1.17.6 Existência de registro da higienização do } \\
\text { reservatório de água ou comprovante de execução de } \\
\text { serviço em caso de terceirização. }\end{array}$ & $\mathrm{x}$ & & \\
\hline $\begin{array}{l}\text { 1.17.7 Encanamento em estado satisfatório e ausência de } \\
\text { infiltrações e interconexões, evitando conexão cruzada } \\
\text { entre água potável e não potável. }\end{array}$ & $\mathrm{x}$ & & \\
\hline $\begin{array}{l}\text { 1.17.8 Existência de planilha de registro da troca periódica } \\
\text { do elemento filtrante. }\end{array}$ & & $\mathrm{x}$ & \\
\hline $\begin{array}{l}\text { 1.17.9 Potabilidade da água atestada por meio de laudos } \\
\text { laboratoriais, com adequada periodicidade, assinados por } \\
\text { técnico responsável pela análise ou expedidos por empresa } \\
\text { terceirizada. }\end{array}$ & $\mathrm{x}$ & & \\
\hline $\begin{array}{l}\text { 1.17.10 Disponibilidade de reagentes e equipamentos } \\
\text { necessários à análise da potabilidade de água realizadas } \\
\text { no estabelecimento. }\end{array}$ & & & $\mathrm{x}$ \\
\hline $\begin{array}{l}\text { 1.17.11 Controle de potabilidade realizado por técnico } \\
\text { comprovadamente capacitado. }\end{array}$ & $\mathrm{x}$ & & \\
\hline $\begin{array}{l}\text { 1.17.12 Gelo produzido com água potável, fabricado, } \\
\text { manipulado e estocado sob condições sanitárias } \\
\text { satisfatórias, quando destinado a entrar em contato com } \\
\text { alimento ou superfície que entre em contato com alimento. }\end{array}$ & & & $\mathrm{X}$ \\
\hline $\begin{array}{l}\text { 1.17.13 Vapor gerado a partir de água potável quando } \\
\text { utilizado em contato com o alimento ou superfície que entre } \\
\text { em contato com o alimento. }\end{array}$ & $\mathrm{X}$ & & \\
\hline
\end{tabular}




\begin{tabular}{|c|c|c|c|}
\hline B - AVALIAÇÃO & SIM & NÃO & $N A\left(^{*}\right)$ \\
\hline \multicolumn{4}{|l|}{ 1.18 MANEJO DOS RESÍDUOS: } \\
\hline \begin{tabular}{|l} 
1.18.1 Recipientes para coleta de resíduos no interior do \\
estabelecimento de fácil higienização e transporte, \\
devidamente identificados e higienizados constantemente; \\
uso de sacos de lixo apropriados. Quando necessário, \\
recipientes tampados com acionamento não manual.
\end{tabular} & $\mathrm{x}$ & & \\
\hline $\begin{array}{l}\text { 1.18.2 Retirada freqüente dos resíduos da área de } \\
\text { processamento, evitando focos de contaminação. }\end{array}$ & $x$ & & \\
\hline $\begin{array}{l}\text { 1.18.3 Existência de área adequada para estocagem dos } \\
\text { resíduos. }\end{array}$ & & $x$ & \\
\hline \multicolumn{4}{|l|}{ 1.19 ESGOTAMENTO SANITÁRIO: } \\
\hline $\begin{array}{l}\text { 1.19.1 Fossas, esgoto conectado à rede pública, caixas de } \\
\text { gordura em adequado estado de conservação e } \\
\text { funcionamento. }\end{array}$ & $x$ & & \\
\hline \multicolumn{4}{|l|}{ 1.20 LEIAUTE: } \\
\hline \begin{tabular}{|l||} 
1.20.1 Leiaute adequado ao processo produtivo: número, \\
capacidade e distribuição das dependências de acordo com \\
o ramo de atividade, volume de produção e expedição.
\end{tabular} & $x$ & & \\
\hline $\begin{array}{l}\text { 1.20.2 Áreas para recepção e depósito de matéria-prima, } \\
\text { ingredientes e embalagens distintas das áreas de produção, } \\
\text { armazenamento e expedição de produto final. }\end{array}$ & $\mathrm{X}$ & & \\
\hline
\end{tabular}

\begin{tabular}{|c|c|c|c|}
\hline B - AVALIAÇÃO & SIM & NÃO & $N A(*)$ \\
\hline \multicolumn{4}{|l|}{ 2. EQUIPAMENTOS, MÓVEIS E UTENSÍLIOS } \\
\hline \multicolumn{4}{|l|}{ 2.1 EQUIPAMENTOS: } \\
\hline $\begin{array}{l}\text { 2.1.1 Equipamentos da linha de produção com desenho e } \\
\text { número adequado ao ramo. }\end{array}$ & $\mathrm{x}$ & & \\
\hline $\begin{array}{l}\text { 2.1.2 Dispostos de forma a permitir fácil acesso e } \\
\text { higienização adequada. }\end{array}$ & $\mathrm{x}$ & & \\
\hline $\begin{array}{l}\text { 2.1.3 Superfícies em contato com alimentos lisas, íntegras, } \\
\text { impermeáveis, resistentes à corrosão, de fácil higienização } \\
\text { e de material não contaminante. }\end{array}$ & $\mathrm{X}$ & & \\
\hline $\begin{array}{l}\text { 2.1.4 Em adequado estado de conservação e } \\
\text { funcionamento. }\end{array}$ & & $\mathrm{x}$ & \\
\hline $\begin{array}{l}\text { 2.1.5 Equipamentos de conservação dos alimentos } \\
\text { (refrigeradores, congeladores, câmaras frigoríficas e } \\
\text { outros), bem como os destinados ao processamento } \\
\text { térmico, com medidor de temperatura localizado em local } \\
\text { apropriado e em adequado funcionamento. }\end{array}$ & & $\mathrm{x}$ & \\
\hline $\begin{array}{l}\text { 2.1.6 Existência de planilhas de registro da temperatura, } \\
\text { conservadas durante período adequado. }\end{array}$ & & $\mathrm{x}$ & \\
\hline
\end{tabular}




\begin{tabular}{|c|c|c|c|}
\hline $\begin{array}{l}\text { 2.1.7 Existência de registros que comprovem que os } \\
\text { equipamentos e maquinários passam por manutenção } \\
\text { preventiva. }\end{array}$ & & $x$ & \\
\hline $\begin{array}{l}\text { 2.1.8 Existência de registros que comprovem a calibração } \\
\text { dos instrumentos e equipamentos de medição ou } \\
\text { comprovante da execução do serviço quando a calibração } \\
\text { for realizada por empresas terceirizadas. }\end{array}$ & & $x$ & \\
\hline \multicolumn{4}{|l|}{ 2.2 MÓVEIS: (mesas, bancadas, vitrines, estantes) } \\
\hline $\begin{array}{l}\text { 2.2.1 Em número suficiente, de material apropriado, } \\
\text { resistentes, impermeáveis; em adequado estado de } \\
\text { conservação, com superfícies íntegras. }\end{array}$ & $\mathrm{x}$ & & \\
\hline $\begin{array}{l}\text { 2.2.2 Com desenho que permita uma fácil higienização } \\
\text { (lisos, sem rugosidades e frestas). }\end{array}$ & $x$ & & \\
\hline \multicolumn{4}{|l|}{\begin{tabular}{|l||l}
2.3 UTENSÍLIOS: & \\
\end{tabular}} \\
\hline $\begin{array}{l}\text { 2.3.1 Material não contaminante, resistentes à corrosão, de } \\
\text { tamanho e forma que permitam fácil higienização: em } \\
\text { adequado estado de conservação e em número suficiente e e } \\
\text { apropriado ao tipo de operação utilizada. }\end{array}$ & $x$ & & \\
\hline $\begin{array}{l}\text { 2.3.2 Armazenados em local apropriado, de forma } \\
\text { organizada e protegidos contra a contaminação. }\end{array}$ & $x$ & & \\
\hline \multicolumn{4}{|l|}{$\begin{array}{l}\text { 2.4 HIGIENIZAÇÃO DOS EQUIPAMENTOS E } \\
\text { MAQUINÁRIOS, E DOS MÓVEIS E UTENSÍLIOS: }\end{array}$} \\
\hline $\begin{array}{l}\text { 2.4.1 Existência de um responsável pela operação de } \\
\text { higienização comprovadamente capacitado. }\end{array}$ & $x$ & & \\
\hline 2.4.2 Freqüência de higienização adequada. & $\mathrm{X}$ & & \\
\hline 2.4.3 Existência de registro da higienização. & & $\bar{x}$ & \\
\hline $\begin{array}{l}\text { 2.4.4 Produtos de higienização regularizados pelo Ministério } \\
\text { da Saúde. }\end{array}$ & $x$ & & \\
\hline $\begin{array}{l}\text { 2.4.5 Disponibilidade dos produtos de higienização } \\
\text { necessários à realização da operação. }\end{array}$ & $\mathrm{x}$ & & \\
\hline $\begin{array}{l}\text { 2.4.6 Diluição dos produtos de higienização, tempo de } \\
\text { contato e modo de uso/aplicação obedecem às instruções } \\
\text { recomendadas pelo fabricante. }\end{array}$ & $\mathrm{x}$ & & \\
\hline $\begin{array}{l}\text { 2.4.7 Produtos de higienização identificados e guardados } \\
\text { em local adequado. }\end{array}$ & $x$ & & \\
\hline $\begin{array}{l}\text { 2.4.8 Disponibilidade e adequação dos utensílios } \\
\text { necessários à realização da operação. Em bom estado de } \\
\text { conservação. }\end{array}$ & $\mathrm{x}$ & & \\
\hline 2.4.9 Adequada higienização. & $\mathrm{x}$ & & \\
\hline \multicolumn{4}{|l|}{ OBSERVAÇÕES } \\
\hline B - AVALIAÇÃO & SIM & NÃO & $\mathrm{NA}(*)$ \\
\hline \multicolumn{4}{|l|}{$\begin{array}{l}\text { 3. MANIPULADORES } \\
\text { 3.1 VESTUÁRIO: }\end{array}$} \\
\hline 3.1 VESTUÁRIO: & & & \\
\hline
\end{tabular}









\begin{tabular}{|c|c|c|c|}
\hline B - AVALIAÇÃO & SIM & NÃO & $\mathrm{NA}\left({ }^{*}\right)$ \\
\hline \multicolumn{4}{|l|}{ 4. PRODUÇÃO E TRANSPORTE DO ALIMENTO } \\
\hline \multicolumn{4}{|l|}{ 4.1 MATÉRIA-PRIMA, INGREDIENTES E EMBALAGENS: } \\
\hline \begin{tabular}{|l|} 
4.1.1 Operações de recepção da matéria-prima, ingredientes \\
e embalagens são realizadas em local protegido e isolado da \\
área de processamento.
\end{tabular} & $\mathrm{x}$ & & \\
\hline $\begin{array}{l}\text { 4.1.2 Matérias - primas, ingredientes e embalagens } \\
\text { inspecionados na recepção. }\end{array}$ & $\mathrm{x}$ & & \\
\hline $\begin{array}{l}\text { 4.1.3 Existência de planilhas de controle na recepção } \\
\text { (temperatura e características sensoriais, condições de } \\
\text { transporte e outros). }\end{array}$ & & $\mathrm{x}$ & \\
\hline \begin{tabular}{|l||} 
4.1.4 Matérias-primas e ingredientes aguardando liberação e \\
aqueles aprovados estão devidamente identificados.
\end{tabular} & $\mathrm{X}$ & & \\
\hline \begin{tabular}{|l||} 
4.1.5 Matérias-primas, ingredientes e embalagens \\
reprovados no controle efetuado na recepção são devolvidos \\
imediatamente ou identificados e armazenados em local \\
separado.
\end{tabular} & $\mathrm{X}$ & & \\
\hline $\begin{array}{l}\text { 4.1.6 Rótulos da matéria-prima e ingredientes atendem à } \\
\text { legislação. }\end{array}$ & $\mathrm{X}$ & & \\
\hline $\begin{array}{l}\text { 4.1.7 Critérios estabelecidos para a seleção das matérias- } \\
\text { primas são baseados na segurança do alimento. }\end{array}$ & $\mathrm{x}$ & & \\
\hline $\begin{array}{l}\text { 4.1.8 Armazenamento em local adequado e organizado; } \\
\text { sobre estrados distantes do piso, ou sobre paletes, bem } \\
\text { conservados e limpos, ou sobre outro sistema aprovado, } \\
\text { afastados das paredes e distantes do teto de forma que } \\
\text { permita apropriada higienização, iluminação e circulação de } \\
\text { ar. }\end{array}$ & $\mathrm{x}$ & & \\
\hline $\begin{array}{l}\text { 4.1.9 Uso das matérias-primas, ingredientes e embalagens } \\
\text { respeita a ordem de entrada dos mesmos, sendo observado } \\
\text { o prazo de validade. }\end{array}$ & $\mathrm{x}$ & & \\
\hline $\begin{array}{l}\text { 4.1.10 Acondicionamento adequado das embalagens a } \\
\text { serem utilizadas. }\end{array}$ & $\mathrm{X}$ & & \\
\hline $\begin{array}{l}\text { 4.1.11 Rede de frio adequada ao volume e aos diferentes } \\
\text { tipos de matérias-primas e ingredientes. }\end{array}$ & $\mathrm{X}$ & & \\
\hline \multicolumn{4}{|l|}{ 4.2 FLUXO DE PRODUÇÃO: } \\
\hline $\begin{array}{l}\text { 4.2.1 Locais para pré - preparo ("área suja") isolados da área } \\
\text { de preparo por barreira física ou técnica. }\end{array}$ & & $\mathrm{x}$ & \\
\hline 4.2.2 Controle da circulação e acesso do pessoal. & $\bar{x}$ & & \\
\hline $\begin{array}{l}\text { 4.2.3 Conservação adequada de materiais destinados ao } \\
\text { reprocessamento. }\end{array}$ & $\mathrm{X}$ & & \\
\hline 4.2.4 Ordenado, linear e sem cruzamento & & $\mathrm{X}$ & \\
\hline
\end{tabular}




\begin{tabular}{|c|c|c|c|}
\hline B - AVALIAÇÃO & SIM & NÃO & $\mathrm{NA}\left({ }^{*}\right)$ \\
\hline \multicolumn{4}{|l|}{ 4.3 ROTULAGEM E ARMAZENAMENTO DO PRODUTO-FINAL: } \\
\hline $\begin{array}{l}\text { 4.3.1 Dizeres de rotulagem com identificação visível e de } \\
\text { acordo com a legislação vigente. }\end{array}$ & & & $\mathrm{x}$ \\
\hline $\begin{array}{l}\text { 4.3.2 Produto final acondicionado em embalagens } \\
\text { adequadas e íntegras. }\end{array}$ & $\mathrm{x}$ & & \\
\hline $\begin{array}{l}\text { 4.3.3 Alimentos armazenados separados por tipo ou grupo, } \\
\text { sobre estrados distantes do piso, ou sobre paletes, bem } \\
\text { conservados e limpos ou sobre outro sistema aprovado, } \\
\text { afastados das paredes e distantes do teto de forma a permitir } \\
\text { apropriada higienização, iluminação e circulação de ar. }\end{array}$ & $\mathrm{X}$ & & \\
\hline 4.3.4 Ausência de material estranho, estragado ou tóxico. & $\mathrm{X}$ & & \\
\hline 4.3.5 Armazenamento em local limpo e conservado & $\mathrm{X}$ & & \\
\hline $\begin{array}{l}\text { 4.3.6 Controle adequado e existência de planilha de registro } \\
\text { de temperatura, para ambientes com controle térmico. }\end{array}$ & & $\mathrm{X}$ & \\
\hline $\begin{array}{l}\text { 4.3.7 Rede de frio adequada ao volume e aos diferentes } \\
\text { tipos de alimentos. }\end{array}$ & $\mathrm{X}$ & & \\
\hline $\begin{array}{l}\text { 4.3.8 Produtos avariados, com prazo de validade vencido, } \\
\text { devolvidos ou recolhidos do mercado devidamente } \\
\text { identificados e armazenados em local separado e de forma } \\
\text { organizada. }\end{array}$ & $\mathrm{X}$ & & \\
\hline $\begin{array}{l}\text { 4.3.9 Produtos finais aguardando resultado analítico ou em } \\
\text { quarentena e aqueles aprovados devidamente identificados. }\end{array}$ & & & $\mathrm{x}$ \\
\hline \multicolumn{4}{|l|}{$\begin{array}{l}\text { 4.4 CONTROLE DE QUALIDADE DO PRODUTO } \\
\text { FINAL: }\end{array}$} \\
\hline 4.4.1 Existência de controle de qualidade do produto final. & & $\mathrm{x}$ & \\
\hline $\begin{array}{l}\text { 4.4.2 Existência de programa de amostragem para análise } \\
\text { laboratorial do produto final. }\end{array}$ & & $\mathrm{X}$ & \\
\hline $\begin{array}{l}\text { 4.4.3 Existência de laudo laboratorial atestando o controle de } \\
\text { qualidade do produto final, assinado pelo técnico da empresa } \\
\text { responsável pela análise ou expedido por empresa } \\
\text { terceirizada. }\end{array}$ & & $\mathrm{X}$ & \\
\hline $\begin{array}{l}\text { 4.4.4 Existência de equipamentos e materiais necessários } \\
\text { para análise do produto final realizadas no estabelecimento. }\end{array}$ & & $\mathrm{X}$ & \\
\hline \multicolumn{4}{|l|}{ 4.5 TRANSPORTE DO PRODUTO FINAL: } \\
\hline $\begin{array}{l}\text { 4.5.1 Produto transportado na temperatura especificada no } \\
\text { rótulo. }\end{array}$ & & & $\mathrm{X}$ \\
\hline $\begin{array}{l}\text { 4.5.2 Veículo limpo, com cobertura para proteção de carga. } \\
\text { Ausência de vetores e pragas urbanas ou qualquer evidência } \\
\text { de sua presença como fezes, ninhos e outros. }\end{array}$ & & & $\mathrm{X}$ \\
\hline 4.5.3 Transporte mantém a integridade do produto. & & & $\mathrm{X}$ \\
\hline $\begin{array}{l}\text { 4.5.4 Veículo não transporta outras cargas que } \\
\text { comprometam a segurança do produto. }\end{array}$ & & & $\mathrm{X}$ \\
\hline 4.5.5 Presença de equipamento para controle de & & & $\mathrm{X}$ \\
\hline
\end{tabular}




\begin{tabular}{|l||l||}
\hline $\begin{array}{l}\text { temperatura quando se transporta alimentos que necessitam } \\
\text { de condições especiais de conservação. }\end{array}$ & \\
\hline OBSERVAÇÕES & \\
\hline
\end{tabular}

\begin{tabular}{|c|c|c|c|}
\hline B - AVALIAÇÃO & SIM & NÃO & $\mathrm{NA}\left({ }^{*}\right)$ \\
\hline 5. DOCUMENTAÇÃO & & & \\
\hline 5.1 MANUAL DE BOAS PRÁTICAS DE FABRICAÇÃO: & & & \\
\hline $\begin{array}{l}\text { 5.1.1 Operações executadas no estabelecimento estão de } \\
\text { acordo com o Manual de Boas Práticas de Fabricação. }\end{array}$ & $\mathrm{X}$ & & \\
\hline $\begin{array}{l}\text { 5.2 PROCEDIMENTOS OPERACIONAIS } \\
\text { PADRONIZADOS: }\end{array}$ & & & \\
\hline $\begin{array}{l}\text { 5.2.1 Higienização das instalações, equipamentos } \\
\text { e utensílios: }\end{array}$ & & & \\
\hline 5.2.1.1 Existência de POP estabelecido para este item. & $\mathrm{X}$ & & \\
\hline 5.2.1.2 POP descrito está sendo cumprido. & $\mathrm{X}$ & & \\
\hline 5.2.2 Controle de potabilidade da água: & & & \\
\hline $\begin{array}{l}\text { 5.2.2.1 Existência de POP estabelecido para controle de } \\
\text { potabilidade da água. }\end{array}$ & & & $\mathrm{X}$ \\
\hline 5.2.2.2 POP descrito está sendo cumprido. & & & $\mathrm{X}$ \\
\hline 5.2.3 Higiene e saúde dos manipuladores: & & & \\
\hline 5.2.3.1 Existência de POP estabelecido para este item. & $\mathrm{X}$ & & \\
\hline 5.2.3.2 POP descrito está sendo cumprido. & & $\mathrm{X}$ & \\
\hline 5.2.4 Manejo dos resíduos: & & & \\
\hline 5.2.4.1 Existência de POP estabelecido para este item. & $\mathrm{x}$ & & \\
\hline 5.2.4.2 O POP descrito está sendo cumprido. & $\mathrm{X}$ & & \\
\hline $\begin{array}{l}\text { 5.2.5 Manutenção preventiva e calibração de } \\
\text { equipamentos. }\end{array}$ & & & \\
\hline 5.2.5.1 Existência de POP estabelecido para este item. & & $\mathrm{X}$ & \\
\hline 5.2.5.2 O POP descrito está sendo cumprido. & & $\mathrm{X}$ & \\
\hline $\begin{array}{l}\text { 5.2.6 Controle integrado de vetores e pragas } \\
\text { urbanas: }\end{array}$ & & & \\
\hline 5.2.6.1 Existência de POP estabelecido para este item. & & $\mathrm{x}$ & \\
\hline 5.2.6.2 O POP descrito está sendo cumprido. & & $\mathrm{X}$ & \\
\hline $\begin{array}{l}\text { 5.2.7 Seleção das matérias-primas, ingredientes e } \\
\text { embalagens: }\end{array}$ & & & \\
\hline 5.2.7.1 Existência de POP estabelecido para este item. & $\mathrm{X}$ & & \\
\hline 5.2.7.2 O POP descrito está sendo cumprido. & $\mathrm{X}$ & & \\
\hline
\end{tabular}




\begin{tabular}{|c|c|c|c|}
\hline \multirow{2}{*}{\multicolumn{4}{|c|}{$\begin{array}{l}\text { B - AVALIAÇÃO } \\
\text { 5.2.8 Programa de recolhimento de alimentos: }\end{array}$}} \\
\hline & & & \\
\hline 5.2.8.1 Existência de POP estabelecido para este item. & & & $\mathrm{X}$ \\
\hline 5.2.8.2 O POP descrito está sendo cumprido. & & & $\mathrm{x}$ \\
\hline OBSERVAÇÕES & & & \\
\hline
\end{tabular}

D - CLASSIFICAÇÃO DO ESTABELECIMENTO

Compete aos órgãos de vigilância sanitária estaduais e distrital, em articulação com o órgão competente no âmbito federal, a construção do panorama sanitário dos estabelecimentos produtores/industrializadores de alimentos, mediante sistematização dos dados obtidos nesse item. O panorama sanitário será utilizado como critério para definição e priorização das estratégias institucionais de intervenção.

( ) GRUPO 1 - 76 A 100\% de atendimento dos itens ( ) GRUPO 2 - 51 A 75\% de atendimento dos itens () GRUPO 3 - 0 A 50\% de atendimento dos itens 
ANEXO 2: PLANTA BAIXA DA UAN 